\title{
ERICACEAE NO PARQUE ESTADUAL DO IBITIPOCA, MINAS GERAIS, BRASIL
}

\author{
ANDRESSA CABRAL*, GERSON OLIVEIRA ROMÃO** \& LUIZ MENINI NETO***
}

\author{
Curso de Ciências Biológicas, Universidade Federal de Juiz de Fora, Juiz de Fora, \\ Minas Gerais, Brasil. Autora para correspondência: acabral@outlook.com.br \\ **Departamento de Ciências Biológicas, Escola Superior de Agricultura Luiz de Queiroz, \\ Universidade de São Paulo, Av. Pádua Dias, 11, 13418-900 - Piracicaba, São Paulo, Brasil. \\ ${ }^{* * *}$ Centro de Ensino Superior de Juiz de Fora, Rua Luz Interior, 345, Estrela Sul, \\ 36030-776 - Juiz de Fora, Minas Gerais, Brasil.
}

\begin{abstract}
Ericaceae in the Parque Estadual do Ibitipoca, Minas Gerais, Brazil). A taxonomic study of the Ericaceae in the Parque Estadual do Ibitipoca (PEIB), located in the Zona da Mata of Minas Gerais State, Brazil, is presented. The PEIB is composed of a vegetation mosaic of which the "campo rupestre" composes the predominant physiognomy. Eighteen taxa belonging to 17 species and three genera were recorded in the study area: Agarista chlorantha, A. ericoides, A. glaberrima, A. hispidula, A. oleifolia var. oleifolia, A. pulchella var. cordifolia, Gaultheria eriophylla var. eriophylla, Gaylussacia amoena, G. brasiliensis var. brasiliensis, G. chamissonis, G. decipiens, G. densa var. densa, G. densa var. oblonga, G. aff. fasciculata, G. pseudogaultheria, G. salicifolia, G. rhododendron, and G. riedelii. Agarista ericoides, Gaylussacia riedelii and G. aff. fasciculata were registered for the first time for Atlantic Forest domain. Descriptions of species, identification keys, illustrations of characters, and comments on geographic distribution, phenology and taxonomy are provided.
\end{abstract}

Key words: Atlantic Forest, biodiversity, "campo rupestre", Ericales, taxonomy.

Resumo (Ericaceae no Parque Estadual do Ibitipoca, Minas Gerais, Brasil). Apresenta-se um estudo taxonômico de Ericaceae do Parque Estadual do Ibitipoca (PEIB), localizado na Zona da Mata do Estado de Minas Gerais, Brasil. O PEIB é composto por um mosaico de vegetação do qual o campo rupestre compõe a fitofisionomia predominante. Foram registradas na área 18 táxons pertencentes a 17 espécies e três gêneros: Agarista chlorantha, A. ericoides, A. glaberrima, A. hispidula, A. oleifolia var. oleifolia, A. pulchella var. cordifolia, Gaultheria eriophylla var. eriophylla, Gaylussacia amoena, G. brasiliensis var. brasiliensis, G. chamissonis, G. decipiens, G. densa var. densa, G. densa var. oblonga, G. aff. fasciculata, G. pseudogaultheria, G. salicifolia, G. rhododendron e G. riedelii. Agarista ericoides, Gaylussacia riedelii e G. aff. fasciculata foram registradas pela primeira vez para o domínio da Floresta Atlântica. São apresentadas descrições das espécies, chaves de identificação, ilustrações de caracteres e comentários sobre distribuição geográfica, fenologia e taxonomia.

Palavras-chave: biodiversidade, campo rupestre, Ericales, Floresta Atlântica, taxonomia.

\section{Introdução}

O Parque Estadual do Ibitipoca (PEIB) localiza-se na Zona da Mata do Estado de Minas Gerais, sudeste do estado, e apresenta um mosaico de fitofisionomias, em que predominam os campos rupestres (Forzza et al. 2013). O PEIB é uma das unidades de conservação mais visitadas no Brasil (Salimena-Pires 1997, Rodela 1998, Vitta 2002), sendo o turismo apontado como a maior pressão antrópica sobre a área (Costa et al. 1998; Menini Neto \& Salimena 2013). Além de ser classificada por Costa et al. (1998) na categoria de "Extrema Importância Biológica", a Serra do Ibitipoca está entre as áreas prioritárias para a conservação da flora estadual, na categoria de importância biológica especial (Drummond et al. 2005).

Ericaceae abrange cerca de 4.100 espécies, pertencentes a 124 gêneros, distribuídas por todo o globo, exceto em áreas desérticas e nos pólos (Luteyn 1995; Judd et al. 2008). Em regiões tropicais possui distribuição predominante em áreas com altitude elevada (Kinoshita-Gouvêa 1980). No Brasil, a família é encontrada principalmente nos estados das regiões Sudeste e Sul, estando representada por 12 gêneros e 98 espécies, das quais 71 são endêmicas, sendo Agarista G. Don ex G. Don e Gaylussacia Kunth os gêneros com maior número de espécies $(21$ e 43 respectivamente) (Souza \& Lorenzi 2012, BFG 2015).

Apesar da alta diversidade no Brasil, poucos trabalhos de cunho florístico com Ericaceae foram realizados, compreendendo algumas floras estaduais e regionais, concentradas nas regiões Sudeste e Sul e frequentemente em áreas de altitude (Romão \& Souza 2003, 2014, Romão et al. 2004, Silva \& Cervi 2006, Marinero et al. 2007, Tekeuchi \& Afonso 2009, Kinoshita \& Romão 2012, Deble et al. 2013, Mezabarba et al. 2013, Cabral et al. 2016a, b). A família é formada em sua maioria por arbustos ou arvoretas, com folhas simples e inflorescências geralmente racemosas, com flores diclamídeas, raramente unissexuadas (Kinoshita-Gouvêa 1980, Souza \& Lorenzi 2012).

A elaboração de floras, além de registrar a riqueza de espécies de uma região, facilitando estudos taxonômicos mais aprofundados, serve também de 
base para políticas de conservação da área e de sua biodiversidade. Deste modo, os objetivos do presente estudo são inventariar as espécies de Ericaceae ocorrentes no Parque Estadual do Ibitipoca, fornecendo descrições das espécies e chave para sua identificação, dados sobre habitats de ocorrência, comentários sobre distribuição geográfica, ecologia e taxonomia, ampliando o conhecimento da flora da Unidade e do Estado de Minas Gerais.

\section{Material e Métodos}

O Parque Estadual do Ibitipoca localiza-se na Serra da Mantiqueira, nos municípios de Lima Duarte e Santa Rita do Ibitipoca, sudeste do estado (214'ㄷ' a $21^{\circ} 43^{\prime} 30^{\prime \prime S}$ e $43^{\circ} 52^{\prime} 35^{\prime \prime}$ a $\left.43^{\circ} 54^{\prime} 15^{\prime \prime W}\right)$, na Zona da Mata Mineira. Possui uma área de 1.488 ha com relevo formado por escarpas altas ou colinas com altitudes variando de 1200 a 1784m (CETEC 1983, Forzza et al. 2013). A área do PEIB é legalmente protegida desde 1965 pelo Instituto Estadual de Florestas, embora sua fundação date de 1973 (Instituto Estadual de Florestas \& Brandt Meio Ambiente 1994, Menini Neto \& Salimena 2013). A vegetação do PEIB abriga um mosaico de fitofisionomias, composto predominantemente por campina nebular (campo rupestre), além do arbustal nebular com predomínio de Eremanthus erythtopappus (D.C.) MacLeish (Asteraceae), campina lenhosa nebular, floresta nebular, nanofloresta nebular, savana arbutivo-arbórea nebular e savana arbustiva nebular (Oliveira-Filho et al. 2013). O clima da região é tropical mesotérmico úmido (Köppen 1931), com invernos frios e secos e verões quentes e úmidos.

A flora da região vem sendo estudada desde 1820 (Menini Neto et al. 2007), com coletas intensificadas a partir dos anos de 1970 e 2001 por pesquisadores da Universidade Federal de Juiz de Fora e Jardim Botânico do Rio de Janeiro respectivamente (Forzza et al. 2013). Além dos dados obtidos pelos estudos anteriores, foram realizadas coletas mensais específicas para este trabalho durante o ano de 2014. Os espécimes férteis foram coletados, fotografados e herborizados segundo metodologia de Fidalgo \& Bononi (1984), tendo suas principais características anotadas em campo.

As identificações, os dados de distribuição geográfica e fenologia foram obtidos das observações em campo, das fichas de exsicatas, além de consultas a literatura especializada (Kinoshita-Gouvêa 1980, Kinoshita 1995, Judd 1995, Romão \& Souza 2003, 2014, Romão et al. 2004, Silva \& Cervi 2006, Kinoshita \& Romão 2010, 2011, 2012, Romão 2011, Mezabarba et al. 2013, Cabral et al. 2016a, b). Foram adotadas as unidades taxonômicas propostas por Sleumer (1967), Judd (1995), Luteyn (1995) e BFG (2015). As descrições dos gêneros foram baseadas nos espécimes coletados no PEIB e literatura supracitada, e a terminologia morfológica seguiu a proposta por
Radford et al. (1974), Harris \& Harris (2003) e Gonçalves \& Lorenzi (2007).

\section{Resultados e Discussão}

Ericaceae está representada no PEIB por 18 táxons pertencentes a 17 espécies, distribuídas em três gêneros: Agarista chlorantha, $A$. ericoides, $A$. glaberrima, A. hispidula, A. oleifolia var. oleifolia, $A$. pulchella var. cordifolia, Gaultheria eriophylla var. eriophylla, Gaylussacia amoena, G. brasiliensis var. brasiliensis, G. chamissonis, G. decipiens, G. densa var. densa, G. densa var. oblonga, G. aff. fasciculata, G. pseudogaultheria, G. salicifolia, G. rhododendron e G. riedelii.

As espécies registradas para 0 PEIB representam cerca de $18 \%$ das Ericaceae ocorrentes no Brasil e aproximadamente $32 \%$ das espécies de Minas Gerais. Dentre os táxons, $A$. oleifolia var. oleifolia, $G$. brasiliensis e $G$. pseudogaultheria destacam-se pela maior distribuição no território brasileiro, sendo que o segundo ocorre em praticamente todos os estados, exceto na Região Norte (BFG 2015). Agarista ericoides, Gaylussacia riedelii e $G$. aff. fasciculata são restritas aos campos rupestres e de maior altitude em Minas Gerais, especialmente na região da Serra do Cipó e Planalto Diamantina, compreendidos na Cadeia do Espinhaço, e no presente estudo, os limites da distribuição geográfica dessas espécies foram ampliados para o domínio da Floresta Atlântica (Romão \& Souza 2014, BFG 2015).

\section{Tratamento taxonômico}

\section{Ericaceae Juss.}

Subarbustos a árvores, lianas, epífitas ou ervas aclorofiladas e micotróficas; tricomas unicelulares ou multicelulares, simples não glandulares, glandulares, dendríticos ou lepidotos; geralmente com glândulas diminutas. Folhas simples, alternas a opostas ou verticiladas, geralmente revolutas, frequentemente coriáceas, decíduas ou não; gemas peroladas; estípulas ausentes. Inflorescência em corimbo, fascículo, panícula, racemo ou flores solitárias; raque comumente bracteada na base; bráctea floral e bractéolas raramente ausentes. Flores monoclinas, raramente diclinas, simetria radial ou levemente bilateral; cálice (3-)5(-7)-lobado; pétalas (34-5(-7), conatas ou raramente livres, corola urceolada, cilíndrica, campanulada ou infundibuliforme; androceu diplostêmone, raramente isostêmone, estames apendiculados ou não, geralmente epipétalos, filetes livres ou unidos, anteras dorsifixas ou basifixas, com 2 poros ou fendas apicais; disco nectarífero intraestaminal comumente presente; gineceu gamocarpelar, ovário súpero ou ínfero, 2-5(10)-locular, óvulos 1-numerosos por lóculo. Fruto 
baga, drupa, nuculânio ou cápsula; sementes de tamanho reduzido.

Bibliografia básica: Cabral et al. (2016a, 2016b), Judd (1984, 1995), Kinoshita-Gouvêa (1980), Kinoshita (1995, 1996), Kinoshita \& Romão (2011,
2012), Luteyn et al. (1995), Marques (1975), Meisner (1863), Mezabarba et al. (2013), Romão \& Souza (2003, 2014), Romão et al. (2004), Romão (2011), Silva \& Cervi (2006), Sleumer (1959, 1967), Takeuchi \& Affonso (2009).

Chave para identificação dos táxons

1. Ovário ínfero, pseudo-10-locular, lóculos uniovulados; fruto do tipo nuculânio

Gaylussacia

2. Tricomas glandulares presentes nas folhas, inflorescências, flores ou frutos.

3. Folhas elípticas a largo-elípticas, raramente ovadas; corola rósea, glabra externamente; raque da inflorescência lisa ......................................................................................................................

3. Folhas estreito-elípticas, oblongas, ovadas, obovadas ou oblanceoladas; corola branca, pubesc
híspido-glandular nos ângulos; raque da inflorescência com glândulas clavadas ou capitadas.

4. Folhas concolores, pubescentes e híspidas com tricomas tectores e glandulares; corola campanulada, híspido-glandular ................................................................................... pseudogaultheria

4'. Folhas marcadamente discolores, pubescentes com tricomas tectores; corola tubuloso-urceolada, pubescente G. aff. fasciculata

2'. Tricomas glandulares ausentes.

5. Cálice com glândula apical

$5^{\prime}$. Cálice desprovido de glândula apical.

6. Folhas com margem inteira.

7. Folhas glandulosas em ambas as faces; pecíolo 1-1,5 mm compr.; bráctea floral largo-elíptica, 3-3,5 mm compr.; bractéolas estreito-elípticas, 2,2-2,3 mm compr.

G. chamissonis

7'. Folhas glandulosas na face abaxial; pecíolo 1,5 a $3 \mathrm{~mm}$ compr.; bráctea floral oval, 6,5-7 mm compr.; bractéolas lineares a lanceoladas, 3,5-4 $\mathrm{mm}$ compr.

8. Ramos densamente tomentosos, com glândulas diminutas; corola 4,8-6 mm compr.......... G. densa var. densa 8'. Ramos esparsamente pubescentes a tomentosos, glândulas ausentes; corola 6-7(-9) mm

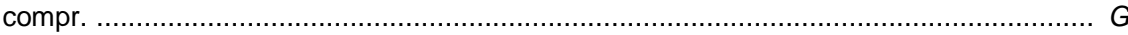

6'. Folhas com margem levemente crenulada, serrilhada, crenada ou crenado-denteada próximo do ápice.

9. Bráctea floral 5,3-8,5 mm compr.; pedicelo 6-10 mm compr.; antera 4,5-7,2 mm compr. G. salicifolia

9'. Bráctea floral 3,5-5 mm compr.; pedicelo 2-6 mm compr.; antera 1,5-3,5 mm compr.

10. Bráctea floral com glândula apical espesso-deltóide; pedicelo 4-6 mm compr.; corola urceolada; glândulas presentes nos frutos.

$10^{\prime}$. Bráctea floral com glândula apical espesso-alongada ou glândula apical ausente; pedicelo 2-4 mm compr.; corola campanulada a largo-campanulada ou tubuloso-campanulada; glândulas ausentes nos frutos.

11. Pecíolo 1-2 mm compr.; raque da inflorescência tomentela a hirsutila; bráctea floral geralmente com glândula apical espesso-alongada; antera 3-3,5 mm compr.; nuculânio depresso-globoso, glabro

11'. Pecíolo 2-3,5 mm compr.; raque da inflorescência pubescente; bráctea floral desprovida de glândula apical espessa; antera 2,8-3 mm compr.; nuculânio globoso, pubescente

G. decipiens

1'. Ovário súpero, 4-5-locular, lóculos multiovulados; fruto cápsula.

12. Filetes retos; tecas apendiculadas, biaristadas; cápsula circundada por cálice carnoso e aderente. Gaultheria eriophylla var. eriophylla

12'. Filetes geniculados; tecas desprovidas de apêndices, truncadas; cápsula não circundada por cálice carnoso e aderente.

13. Tricomas glandulares presentes nas flores.

14. Folhas estreito-ovadas, margem inteira a levemente ondulada, ápice arredondado; pecíolo 1,7-2mm compr.; raque da inflorescência 0,8-1,2 cm compr.; bráctea floral ca. $1.7 \mathrm{~mm}$ compr., bractéolas ca. $1 \mathrm{~mm}$ compr.; cálice 2,7 - $3 \mathrm{~mm}$ compr.; corola 6-7 mm compr.; filete ca. $4 \mathrm{~mm}$ compr., densamente pubescente

A. chlorantha

14'. Folhas linear-lanceoladas, margem levemente serreada, ápice agudo; pecíolo 0,8-1 mm compr.; raque da inflorescência 2-9 cm compr.; bráctea floral 3-4,2 mm compr.; bractéolas 2,5-3,7 mm compr.; cálice 4-6 mm compr.; corola 7,5-12 mm compr.; filete 5,5-7 mm compr., lanoso A. ericoides

13'. Tricomas glandulares ausentes nas flores.

15. Pecíolo 3-36 mm compr.; corola alva a alvo-esverdeada.

16. Pecíolo 13-36 mm compr., flexível; raque da inflorescência glabra; bráctea floral 2,5-4,3 mm compr.; filete 3-5,8 mm compr.; ovário glabro; cápsula glabra ....

16'. Pecíolo 3-6 mm compr., rígido; raque da inflorescência tomentosa; bráctea floral 1-1,2 mm compr.; filete 6-7 mm compr.; ovário pubescente na porção basal; cápsula esparsamente pubérula

15'. Pecíolo 1,5-2 mm compr.; corola rósea, róseo-avermelhada a vermelha.

17. Folhas lanceoladas; pecíolo ca. $1,5 \mathrm{~mm}$ compr.; raque da inflorescência $0,5-2 \mathrm{~cm}$ compr.

17 '. Folhas ovadas a orbiculares; pecíolo 1,8-2 mm compr.; raque da inflorescência 1-3 cm compr. 


\section{Agarista D. Don ex G. Don}

Subarbustos a árvores; ramos glabros a pilosos. Folhas alternas a subopostas, esparsas ou densamente dispostas, subcoriáceas a rigidamente coriáceas; margem plana a revoluta, inteira, levemente ondulada ou serreada, glabra a pilosa; pecíolo rígido a flexível. Inflorescência racemosa ou paniculada, bracteada na base da raque; bráctea floral 1, inserida na base do pedicelo; bractéolas 2, inseridas da base até 0 ápice do pedicelo. Flores pentâmeras radiais, pendentes, bissexuadas; cálice conato na base, lobos curtos; corola gamopétala, tubulosa, urceolada a cilíndrica, alva a avermelhada; estames 10, iguais entre si; filetes geniculados, achatados, dorso frequentemente piloso, anteras ovoide-oblongas, bífidas, dorsifixas, deiscência poricida, tecas desprovidas de apêndice, truncadas; ovário súpero, globoso, 5-locular, lóculo multiovulado. Cápsula loculicida, depresso-globosa a ovoide, não circundada por cálice carnoso e aderente; sementes numerosas, fusiformes.

Agarista engloba 31 espécies, ocorrendo predominantemente nas Américas. No Brasil, estão relacionadas 21 espécies com distribuição predominante nas regiões de maior altitude das regiões Sudeste e Sul (Judd 1995, BFG 2015). No PEIB, são encontradas seis espécies ocorrendo em áreas de campo rupestre, borda e interior de floresta nebular e mata de galeria.

1.1. Agarista chlorantha (Cham.) G.Don, Gen. hist. 3: 838. 1934.

Fig. 1A-D

Arbusto, ca. $1,8 \mathrm{~m}$ alt. Tricomas tectores alvos, presentes nos ramos, folhas, raque da inflorescência, flores e frutos; tricomas glandulares presentes nas flores; glândulas ausentes. Folhas coriáceas, estreito-ovadas, 0,8-2,4 x 0,32-1,1 cm, esparsamente pubescentes na porção basal da nervura central de ambas as faces, base cordada, margem revoluta, inteira a levemente ondulada, ápice arredondado, mucronado; pecíolo 1,7-2 mm compr., rígido. Inflorescência racemosa, axilar; raque 0,8-1,2 cm compr., densamente pubescente; bráctea floral linear-lanceolada, ca. 1,7 mm compr., pubescente; bractéolas linear-lanceoladas, ca. $1 \mathrm{~mm}$ compr., indumento como na bráctea. Pedicelo 2-4,5 mm compr.; cálice 2,7-3 mm compr., externamente esparsamente pubescente e lanoso-glandular; corola alva, cilíndrico-urceolada, 6-7 mm compr., externamente glabra; filete ca. $4 \mathrm{~mm}$ compr., dorso densamente pubescente, antera ca. 1,5 mm compr.; ovário esparsamente pubescente. Cápsula castanhoacinzentada, depresso-globosa, 5-7 mm diâm., tomentosa.

Material examinado: Serra do Ibitipoca, 30.IX.1970, bot., U. Confúcio s.n. (CESJ 9401, RB 151247).
Material adicional examinado: MINAS GERAIS: Olaria. Serrinha, Sítio do Rinaldo Degredo, 22.VIII.2009, bot., fl. e fr., J.H.C. Ribeiro et al. 193 (CESJ). Rio Preto. Ninho da Égua, 28.IV.2008, fr., F.S. Souza et al. 427 (CESJ). Serra da Caveira d'Anta, Fazenda da Tiririca, 23.II.2004, fr., $K$. Antunes et al. 26 (CESJ, ESA).

Agarista chlorantha possui semelhanças em aspectos vegetativos com duas espécies que também ocorrem na área de estudo, $A$. ericoides e $A$. hispidula, por apresentarem hábito arbustivo, folhas coriáceas, com margem revoluta e dimensões semelhantes, além de pecíolo rígido não ultrapassando $2 \mathrm{~mm}$ de comprimento. Porém, $A$. chlorantha diferencia-se de $A$. ericoides por apresentar principalmente folhas estreitoovadas, com margem inteira a levemente ondulada e ápice arredondado, e de $A$. hispidula pela presença de tricomas glandulares, flores com corola alva e glabra, além de cálice esparsamente pubescente e lanosoglandular. Endêmica do Brasil, A. chlorantha ocorre em áreas de maior altitude da Floresta Atlântica de Minas Gerais até Santa Catarina, e pelo Brasil Central no Distrito Federal, muitas vezes associada a áreas úmidas e rochosas (Kinoshita \& Romão 2012, BFG 2015). Na área do PEIB, foi encontrada em campo rupestre e coletada com botões florais apenas no mês de setembro.

Ilustrações em Meisner (1863, sob Leucothoe chlorantha, $L$. serrulata e $L$. subcanescens), Marques (1975, sob L. chlorantha e L. serrulata), KinoshitaGouvêa (1980, sob L. chlorantha), Judd (1995), Silva \& Cervi (2006), Kinoshita \& Romão (2012) e Cabral et al. (2016a).

1.2. Agarista ericoides Taubert, Bot. Jahrb. Syst. 17: 512.1893.

Fig. 1E-I, $2 \mathrm{~A}$

Arbusto, 0,3-2 m alt. Tricomas tectores alvos, presentes nas folhas, raque da inflorescência, flores e frutos; tricomas glandulares presentes nos ramos, folhas, raque da inflorescência e flores; glândulas ausentes. Folhas coriáceas, linear-lanceoladas, 0,5$1,4 \times 0,25-0,45 \mathrm{~cm}$, glabras a esparsamente pubescentes na porção basal da nervura central da face adaxial, lanoso-glandulares na margem e nervura central da face abaxial, base cordada, margem fortemente revoluta, levemente serreada, com tricomas glandulares nos dentes, ápice agudo, mucronado; pecíolo 0,8-1 $\mathrm{mm}$ compr., rígido. Inflorescência racemosa, axilar ou terminal; raque 2-9 $\mathrm{cm}$ compr., densamente pubescente e lanosoglandular; bráctea floral linear-lanceolada, 3-4,2 mm compr., pubescente e lanoso-glandular; bractéolas linear-lanceoladas, 2,5-3,7 $\mathrm{mm}$ compr., indumento como na bráctea. Pedicelo 4,5-6 mm compr.; cálice 4$6 \mathrm{~mm}$ compr., esparsamente pubescente e lanosoglandular externamente; corola alva, cilíndricourceolada, 7,5-12 mm compr., externamente glabra a esparsamente pubescente nos ângulos; filete 5,5-7 $\mathrm{mm}$ compr., dorso lanoso, antera 1,2-1,8 mm compr.; 

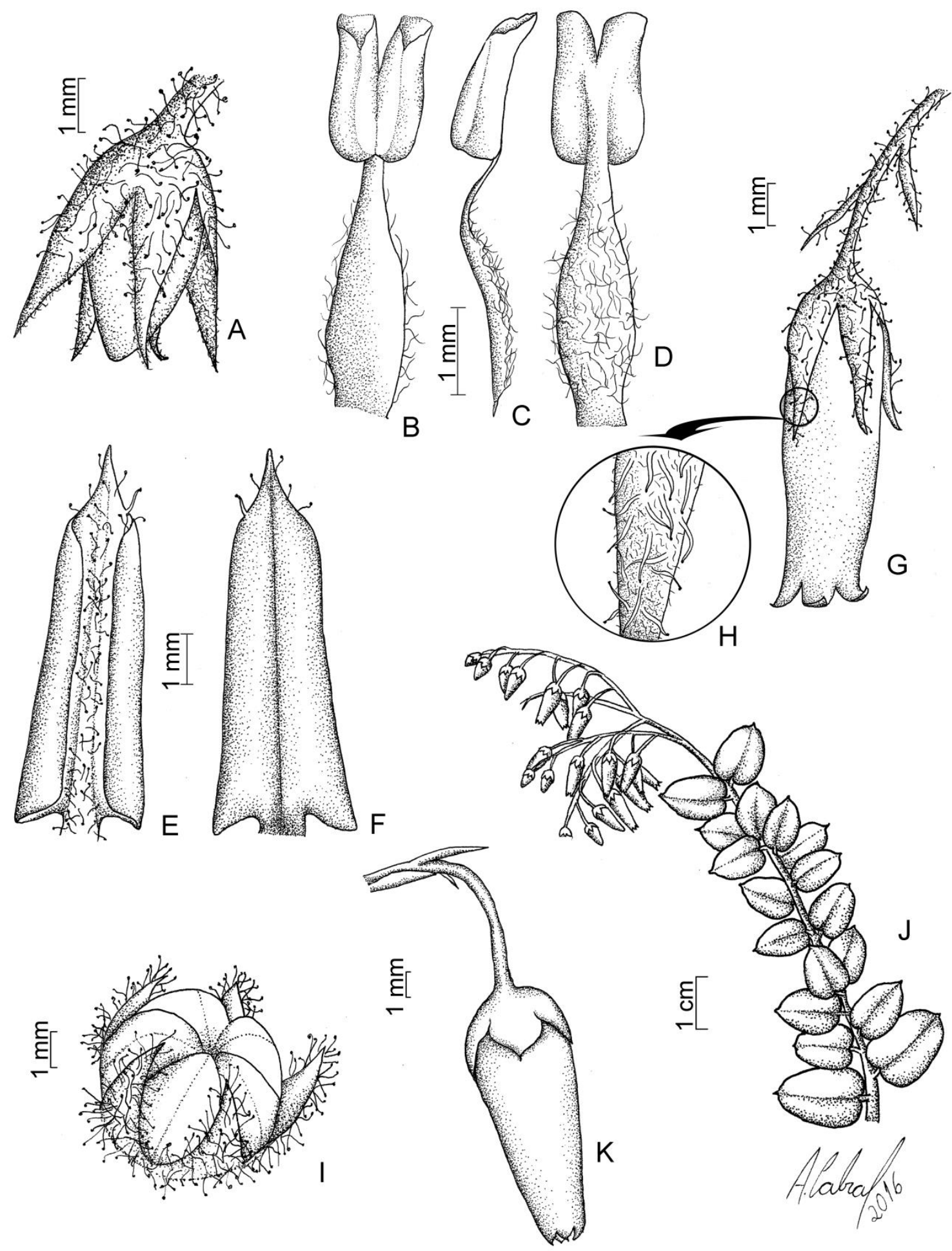

Fig. 1: A-D. Agarista chlorantha, A. botão floral, B. vista ventral do estame, C. vista lateral do estame, D. vista dorsal do estame (Confúcio 9401). E-I. Agarista ericoides, E. face abaxial da folha, F. face adaxial da folha, G. vista geral da flor e bractéolas, H. detalhe do indumento no cálice, I. cápsula imatura (Silva et al. 1309, Forzza 4235). J-K. Agarista pulchella var. cordifolia, J. ramo florido, K. vista geral da flor, bráctea e bractéolas (Cabral 102). 
ovário pubescente na porção apical. Cápsula castanho-esverdeada, depresso-globosa, 4,5-5,5 mm diâm., pubescente.

Material examinado: Lima Duarte. Parque Estadual do Ibitipoca. Cachoeira dos Macacos, trilha para a caverna da Ponte de Pedra, 26.X.2004, fl., B.R. Silva et al. 1350 (CESJ, RB). Caminho para a Lagoa Seca, 25.IX.2001, fl. e fr., L.C. Giordano et al. 2423 (CESJ, RB). Entre o Cruzeiro e o Morro da Lombada, 3.XI.2000, fl., M.A. Heluey 5 (CESJ). Monjolinho, 19.IX.2006, fl., R.C. Forzza et al. 4235 (CESJ, RB). Próximo à Lombada, 3.VIII.2014, fr., A. Cabral et al. 81 (CESJ). Trilha para o Paredão, 28.VII.91, fl. e fr., M. Eiterer s.n. (CESJ 24890). Trilha entre o Monjolinho e a Lagoa Seca, 30.III.2004, fr., B.R. Silva et al. 1309 (CESJ, ESA, RB). Serra do Ibitipoca, 30.IX.1970, bot., L. Krieger s.n. (CESJ 9398).

Agarista ericoides é caracterizada pelas suas folhas fortemente revolutas, de pequenas dimensões e pelo indumento glandular muito variável, estando morfologicamente relacionada com $A$. chlorantha, $A$. hispidula e $A$. organensis (Gardner) Hook. ex Nied., como destacado por Judd (1995). Destas espécies, $A$. chlorantha e $A$. hispidula também ocorrem no PEIB. Agarista ericoides diferencia-se de $A$. chlorantha pela presença de folhas linear-lanceoladas, com margem levemente serreada e ápice agudo, e de $A$. hispidula por apresentar tricomas glandulares nos ramos, folhas, raque da inflorescência e flores, folhas com margem levemente serreada e flores com corola alva. Essa espécie ocorre apenas em áreas de maiores altitude de Minas Gerais (BFG 2015). Na área de estudo foi encontrada frequentemente em campo rupestre, ocorrendo também em borda de floresta nebular e em mata de galeria. No PEIB, foi coletada com flores em julho e de setembro a novembro, e com frutos em março, e de julho a setembro e novembro.

llustrações em Kinoshita-Gouvêa (1980, sob Leucothoe ericoides) e Judd (1995).

1.3. Agarista glaberrima (Sleumer) Judd, J. Arnold Arbor. 65: 336. 1984.

Fig. 2B

Arbusto a arvoreta, 1,5-3 $\mathrm{m}$ alt. Tricomas tectores alvos, presentes nas folhas e flores; tricomas glandulares ausentes; glândulas ausentes. Folhas subcoriáceas, frequentemente conduplicadas, ovadas a oval-lanceoladas, 1,3-7,5 x 0,8-3,5 cm, glabras em ambas as faces ou esparsamente pubescentes na porção mediana e basal da nervura central da face adaxial, frequentemente com fovéolas conspícuas, nigrescentes, próximo à nervura central da face abaxial, base arredondada a assimétrica, margem plana, inteira, ápice agudo a atenuado, mucronado; pecíolo 13-36 mm compr., flexível. Inflorescência racemosa, axilar ou terminal; raque 2,3-9,6 cm compr., glabra; bráctea floral estreito-triangular, 2,5-4,3 mm compr., ciliada a pubescente; bractéolas deltoides, 1-2 mm compr., ciliadas. Pedicelo 5,3-7 mm compr.; cálice 1,3-1,7 mm compr., ciliado; corola alva a alvoesverdeada, tubuloso-urceolada, 8-10 mm compr., externamente glabra; filete $3-5,8 \mathrm{~mm}$ compr., dorso pubescente, antera 1,3-1,7 mm compr.; ovário glabro. Cápsula castanha, depresso-globosa a globosa, 4-7 mm diâm., glabra.

Material examinado: Lima Duarte. Parque Estadual do Ibitipoca. Próximo à Janela do Céu, 20.IX.2006, fl., R.C. Forzza et al. 4264 (CESJ). Idem, 6.VIII.2014, bot. e fr., A. Cabral et al. 91 (CESJ). Trilha para Cachoeira dos Macacos, proximidade do mirante, 15.XI.2014, fl. e fr., G.O. Romão \& A.P.T. Dantas 3493, 3494 e 3495 (ESA). Idem, trilha para a caverna da Ponte de Pedra, 26.X.2004, fl. e fr., B.R. Silva et al. 1353 (CESJ). Idem, 4.VIII.2014, fl. e fr., A. Cabral et al. 84 e 94 (CESJ).

Agarista glaberrima pode ser facilmente confundida com $A$. oleifolia var. oleifolia na área de estudo por possuírem semelhanças morfológicas tanto em caracteres vegetativos, como folhas subcoriáceas, com margem plana e inteira, de dimensões semelhantes (1,3-7,5 x 0,8-3,5 cm em $A$. glaberrima e $(0,7-) 1,8-6,8 \times 0,35-1,95 \mathrm{~cm}$ em $A$. oleifolia var. oleifolia), quanto reprodutivas, como flores com corola alva a alvo-esverdeada e tubuloso-urceolada. Porém, A. glaberrima diferencia-se por apresentar pecíolo flexível de 13-36 $\mathrm{mm}$ de comprimento, além de raque da inflorescência e pedicelo glabros. Agarista glaberrima é endêmica das áreas de maior altitude em Minas Gerais, principalmente ao longo da Cadeia do Espinhaço (Romão \& Souza 2014, BFG 2015). Na área de estudo foi encontrada em campo rupestre, borda de floresta nebular e mata de galeria e coletada com flores de agosto a novembro, com frutos em agosto e de outubro a novembro.

llustrações em Judd (1995), Romão \& Souza (2004) e Cabral et al. (2016a).

1.4. Agarista hispidula (DC.) Hook. f. ex Nied., Bot. Jahrb. Syst. 11: 236. 1889.

Fig. 2C

Arbusto, ca $1,5 \mathrm{~m}$ alt. Tricomas tectores alvos, presentes nos ramos, folhas, raque da inflorescência, flores e frutos; tricomas glandulares ausentes; glândulas ausentes. Folhas coriáceas, lanceoladas, $1-2,7 \times 0,35-0,8 \mathrm{~cm}$, tomentosas na porção basal e na nervura central da face adaxial, densamente tomentosas em todo o limbo da face abaxial, base cordada, margem revoluta, inteira a levemente ondulada, ápice agudo a arredondado, mucronado; pecíolo ca. 1,5 mm compr., rígido. Inflorescência racemosa, axilar; raque $0,5-2 \mathrm{~cm}$ compr., densamente tomentosa; bráctea floral deltoide, 1,2-1,8 $\mathrm{mm}$ compr., pubescente a densamente pubescente; bractéolas linearlanceoladas, 1-1,5 mm compr., indumento como na bráctea. Pedicelo 5-7 mm compr.; cálice 2-2,5 mm compr., externamente densamente tomentoso; corola rósea a avermelhada, urceolada, $8-9 \mathrm{~mm}$ compr., externamente tomentosa, mais densamente próximo aos lobos; filete 4,2-5 $\mathrm{mm}$ compr., dorso esparsamente tomentoso, antera 1,5-2 mm compr.; 
ovário densamente pubescente. Cápsula castanha, depresso-globosa, 5-6 mm diâm., tomentosa.

Material examinado: Lima Duarte. Parque Estadual do Ibitipoca. Próximo à Janela do Céu, 6.VIII.2014, fl. e fr., $A$. Cabral et al. 89 (CESJ).

Agarista hispidula está relacionada na área de estudo com $A$. chlorantha e $A$. ericoides como espécies morfologicamente mais semelhantes, das quais é distinta principalmente por apresentar flores com corola rósea a avermelhada e cálice densamente tomentoso, além da ausência de tricomas glandulares na planta. É endêmica do Brasil, ocorrendo em áreas de maior altitude da Floresta Atlântica em Minas Gerais, Rio de Janeiro e São Paulo, e pelo Brasil Central em Goiás, muitas vezes associadas à cursos d'água (Kinoshita \& Romão 2012, BFG 2015). Foi encontrada no PEIB em afloramentos rochosos dos campos rupestres e coletada com flores e frutos no mês de agosto.

Ilustrações em Meisner (1863, sob Leucothoe brevifolia, L. hispidula e L. intermedia), KinoshitaGouvêa (1980, sob L. intermedia), Judd (1995), Kinoshita \& Romão (2012), Mezabarba et al. (2013) e Cabral et al. (2016a).

1.5. Agarista oleifolia (Cham.) G.Don var. oleifolia, Gen. hist. 3: 838. 1834.

Fig. 2D

Arbusto, arvoreta a árvore, 1,4-6 m alt. Tricomas tectores alvos, presentes nos ramos, folhas, raque da inflorescência, flores e frutos; tricomas glandulares ausentes; glândulas ausentes. Folhas subcoriáceas, lanceoladas, elípticas e oblongas, $(0,7$ )1,8-6,8 x 0,35-1,95 cm, glabras a pubescentes na porção mediana e basal da nervura central de ambas as faces, às vezes com fovéolas conspícuas, nigrescentes, próximo à nervura central da face abaxial, base cuneada a arredondada, por vezes assimétrica e levemente cordada, margem plana, inteira, ápice agudo a cuneado, mucronado; pecíolo 3$6 \mathrm{~mm}$ compr., rígido. Inflorescência racemosa, axilar; raque 2,3-6,2 cm compr., tomentosa; bráctea floral estreito-triangular a deltoide, 1-1,2 mm compr., pubérula; bractéolas deltoides, 1,3-1,5 mm compr., indumento como na bráctea. Pedicelo 5-7 mm compr.; cálice 1,7-2 mm compr., ciliado; corola alva a alvoesverdeada, tubuloso-urceolada, 7-9 mm compr., externamente glabra; filete 6-7 $\mathrm{mm}$ compr., dorso tomentoso, antera 1-1,5 mm compr.; ovário pubescente na porção basal. Cápsula castanha, depresso-globosa, 5-7 mm diâm., esparsamente pubérula.

Material examinado: Lima Duarte. Parque Estadual do Ibitipoca. Cachoeira das Elfas, 5.VIII.2014, fl. e fr., $A$. Cabral et al. 85 (CESJ). Cachoeirinha, 27.VI.2001, fl. e fr., L.C. Giordano et al. 2442 (CESJ). Próximo à Gruta das Bromélias, 1.VIII.2014, fr., A. Cabral et al. 72 (CESJ).
Próximo à Gruta do Pião, 2.VIII.2014, fl. e fr., $A$. Cabral et al. 77 (CESJ). Serra do Ibitipoca, 27.IX.1970, fl., L. Krieger et al. s.n. (CESJ 9264). Idem, 3.XI.1973, fr., L. Krieger s.n. (CESJ 13226).

Agarista oleifolia var. oleifolia possui semelhanças morfológicas com $A$. glaberrima, como mencionado anteriormente. Porém, $A$. oleifolia diferencia-de por apresentar pecíolo rígido com 3-6 $\mathrm{mm}$ de comprimento e pelo indumento nos ramos, raque da inflorescência e pedicelo. Judd (1984) reconhece duas variedades com base principalmente no indumento da raque da inflorescência. Apenas $A$. oleifolia var. oleifolia é encontrada na área de estudo, sendo caracterizada por possuir raque da inflorescência esparsa a densamente pubescente. Ocorre em áreas de maiores altitudes da Floresta Atlântica no Espírito Santo até o Paraná, distribuindose também pelo Brasil Central em Goiás e Mato Grosso e ao longo da Cadeia do Espinhaço em Minas Gerais e Bahia, frequentemente associada à cursos d'água (Romão \& Souza 2014, BFG 2015). No PEIB foi encontrada em campo rupestre, borda e interior de floresta nebular e mata de galeria, e coletada com flores em junho, agosto e setembro, e com frutos em junho, agosto e novembro.

Ilustrações em Meisner (1863, sob Leucothoe oleifolia), Kinoshita-Gouvêa (1980, sob L. oleifolia), Judd (1984, 1995), Romão \& Souza (2003), Kinoshita \& Romão (2012), Mezabarba et al. (2013), Romão \& Souza (2014) e Cabral et al. (2016a,b).

1.6. Agarista pulchella Cham. ex G.Don var. cordifolia (Meisn.) Judd, J. Arnold Arb. 65: 316. 1984.

Fig. 1J-K, 2E

Subarbusto a arbusto, 0,3-1,5 m alt. Tricomas tectores alvos, presentes nos ramos, folhas, raque da inflorescência, flores e frutos; tricomas glandulares ausentes; glândulas ausentes. Folhas coriáceas, ovadas a orbiculares, 0,4-3,1 x 0,4-2 cm, pubescentes na porção basal ou em toda a nervura central de ambas as faces, às vezes com fovéolas conspícuas, nigrescentes, próximo à nervura central da face abaxial, base cordada, margem plana a levemente revoluta, inteira, ápice levemente emarginado a arredondado, mucronado; pecíolo 1,8-2 mm compr., rígido. Inflorescência racemosa ou paniculada, axilar ou terminal; raque $1-3 \mathrm{~cm}$ compr., densamente tomentosa; bráctea floral estreito-triangular, 1,9-3 mm compr., tomentosa; bractéolas estreito-triangulares, 1,5-2 mm compr., indumento como na bráctea. Pedicelo 7-9 mm compr.; cálice 1,8-2,5 mm compr., externamente esparsamente pubescente, mais densamente na porção basal e margem dos lobos; corola róseo-avermelhada, urceolada a cilíndrica, 6,5$9 \mathrm{~mm}$ compr., externamente glabra a pubescente; filete ca. $5 \mathrm{~mm}$ compr., dorso esparsamente pubescente, antera ca. 1,5 mm compr.; ovário densamente pubescente. Cápsula castanha, depresso-globosa, 4,5-6 mm diâm., pubescente. 
Material examinado: Lima Duarte. Parque Estadual do Ibitipoca. 25.III.2001, fl. e fr., R.M. Castro et al. 213 (CESJ). Caminho entre a Lombada e a Gruta do Monjolinho, 2.XI.2014, fl., A. Cabral et al. 102 (CESJ). Próximo à Gruta dos Viajantes, 2.VIII.2014, fl. e fr., $A$. Cabral et al. 74 (CESJ).

Agarista pulchella var. cordifolia é mais próxima morfologicamente de $A$. minensis (Glaz. ex Sleumer) Judd e $A$. oleifolia (Judd 1995), sendo que apenas a última também ocorre no PEIB, podendo ser distinguida principalmente pela base das folhas fortemente cordada. Segundo Kinoshita-Gouvêa (1980), esta espécie também pode apresentar corola branca, fato não observado nos espécimes do PEIB. Apenas uma das variedades reconhecidas por Judd (1984) ocorre no PEIB, e segundo Kinoshita \& Romão (2012) pode ser diferenciada da variedade típica por apresentar folhas subcoriáceas, com pilosidade em toda a lâmina e flores com corola glabra, enquanto que em $A$. pulchella var. pulchella ocorrem folhas coriáceas, com face abaxial glabra ou com pilosidade apenas na nervura principal e flores com corola densamente pubescente. É endêmica do Brasil, ocorrendo em campos de maiores altitudes no Cerrado e na Floresta Atlântica de Minas Gerais até Santa Catarina (BFG 2015). No PEIB foi registrada em campo rupestre, e coletada com flores em março, agosto e novembro, e com frutos em março e agosto.

llustrações em Meisner (1863, sob Leucothoe cordifolia) e Kinoshita \& Romão (2012).

\section{Gaultheria L.}

Subarbustos a árvores; ramos glabros a pilosos. Folhas alternas, comumente não adensadas, geralmente coriáceas; margem plana a revoluta, inteira ou serreada a crenada, glabra a híspida; pecíolo rígido. Inflorescência racemosa, paniculada, fasciculada ou flores solitárias, bracteada ou não na base da raque; bráctea floral 1 , foliácea, inserida na base do pedicelo; bractéolas 2-12, inseridas da base até o ápice do pedicelo. Flores tetra ou pentâmeras, radiais, pendentes, bissexuadas; cálice conato na base, articulado com o pedicelo, lobos curtos ou não; corola gamopétala, urceolada a cilíndrica, raramente campanulada, alva a avermelhada; estames 8-10, iguais entre si; filetes retos, achatado-subulados, dorso glabro o piloso, anteras oblongas, bífidas, dorsifixas, deiscência poricida ou por pequena fenda, tecas apendiculadas, biaristadas; ovário súpero, globoso, 4-5-locular, lóculo multiovulado. Cápsula loculicida, frequentemente globosa, circundada por cálice carnoso e aderente; sementes numerosas, ovoides ou anguladas, lateralmente comprimidas.

Gaultheria compreende aproximadamente 130 espécies distribuídas nas regiões temperadas e tropicais das Américas, Himalaia/Indo-China, sudeste da Ásia e Oceania (Bush et al. 2009; Fritsch et al. 2011). No Brasil, estão relacionadas 10 espécies e um híbrido natural, com distribuição predominante nas regiões de maiores altitudes nos domínios da Floresta Atlântica nas regiões Sudeste e Sul e da Floresta Amazônica (Judd 1995, BFG 2015). No PEIB, é encontrada somente $G$. eriophylla var. eriophylla.

2.1. Gaultheria eriophylla (Pers.) Sleumer ex Burtt var. eriophylla, Bot. Mag. 170: t. 254. 1955.

Fig. 2F

Subarbusto a arbusto, 0,2-1,5 m alt. Tricomas tectores ferrugíneos, presentes nos ramos, folhas, raque da inflorescência, flores e frutos, alvos, presentes nas folhas, raque da inflorescência, flores e frutos; tricomas glandulares ausentes; glândulas ausentes. Folhas coriáceas, ovadas a largo-elípticas, raramente orbiculares, 2,5-9 x 1,3-5,6 cm, esparsamente tomentosas, mais densamente na nervura central da face adaxial, esparsa a densamente tomentosas a lanosas na face abaxial, base obtusa a arredondada, margem levemente revoluta, inteira, ápice agudo a obtuso, mucronado; pecíolo 2,5-5 mm compr., rígido. Inflorescência racemosa, axilar; raque 3-8,5 cm compr., densamente tomentosa a lanosa e pubescente; bráctea floral elíptica a ovada, 4-11 mm compr., densamente tomentosa a lanosa; bractéolas linear-lanceoladas, 2-2,8 mm compr., indumento como na bráctea. Pedicelo 4-4,5 mm compr.; cálice 2-2,8 $\mathrm{mm}$ compr., densamente tomentoso a lanoso e pubescente externamente; corola rósea, urceolada, 4,3-5 mm compr., densamente tomentosa a lanosa externamente; filete 2,5-2,8 $\mathrm{mm}$ compr., dorso tomentoso, tecas 1,3-1,5 $\mathrm{mm}$ compr.; ovário tomentoso. Cápsula castanha, depresso-globosa, 3,5$4 \mathrm{~mm}$ diâm., esparsamente tomentosa a lanosa.

Material examinado: Lima Duarte. Parque Estadual do Ibitipoca. Campo Rupestre nas proximidades do Pico do Pião, 25.IX.2001, fl. e fr., L.C. Giordano et al. 2422 (RB). Escada que leva ao Pico do Pião, 2.VIII.2014, fl., A. Cabral et al. 76 (CESJ). Extremidade norte, 24.III.2002, fl., A.S.M. Valente et al. 174 (CESJ). Próximo ao Pico do Pião, 2.VIII.2014. fl., A. Cabral et al. 75 (CESJ). Trilha entre a Gruta do Fugitivo e Cascatinha, 11.III.2004, fl., R.C. Forzza et al. 3194 (CESJ). Serra de Ibitipoca, 13.V.1970, fl. e fr., L. Krieger s.n. (CESJ 8657, ESA). Idem, 29.IX.2001, fl., U.C. Câmara et al. s.n. (CESJ 9353).

Gaultheria eriophylla var. eriophylla pode ser facilmente diferenciada das demais espécies de Ericaceae encontradas no PEIB por apresentar indumento densamente ferrugíneo-tomentoso na face abaxial das folhas e na raque da inflorescência (Kinoshita \& Romão 2012). É a única das duas variedades da espécie que ocorre no Brasil, sendo endêmica da Região Sudeste (BFG 2015), enquanto que a segunda variedade, $G$. eriophylla var. mucronata (J. Rémy) Luteyn, é restrita ao Peru e Bolívia (Stevens 1971, Luteyn 1995). No PEIB, foi encontrada em áreas de campo rupestre e coletada com flores em março, maio, agosto e setembro, e com frutos em maio e setembro. 
Ilustrações em Meisner (1863, sob $G$. ferruginea), Kinoshita-Gouvêa (1980), Kinoshita \& Romão (2012), Mezabarba et al. (2013) e Cabral et al. (2016a, b).

\section{Gaylussacia Kunth}

Subarbustos a arbustos; ramos glabros a pilosos. Folhas alternas ou subopostas, esparsas ou adensadas, cartáceas a rigidamente coriáceas, margem plana a revoluta, inteira a levemente serreada, crenado-denteada ou crenulada, glabra a pilosa; pecíolo rígido. Inflorescência tipo racemo ou panícula, bracteada na base da raque; bráctea floral 1 , inserida na base do pedicelo; bractéolas 2 , inseridas da porção basal a apical do pedicelo. Flores pentâmeras actinomorfas, pendentes, bissexuadas; cálice conato na base, lobos curtos; corola gamopétala, urceolada, campanulada ou tubulosa, alva ou rósea a avermelhada; estames 10, iguais entre si; filetes retos, achatados, dorso frequentemente piloso, anteras dorsifixas, tecas longo-tubulosas, bífidas, deiscência poricida ou por pequena fenda apical introrsa; ovário ínfero, pseudo-10-locular, lóculo uniovulado. Nuculânio, globoso a ovoide, 10 pirênios; sementes lenticulares.

Gaylussacia compreende 54 espécies distribuídas pela porção subtropical atlântica da América do Norte e na América do Sul tropical e subtropical, sendo ausente na América Central (Sleumer 1967; Kinoshita 1995; Romão 2011). No Brasil, estão relacionadas 43 espécies com distribuição predominante nos campos rupestres da Cadeia do Espinhaço e campos de altitude da Floresta Atlântica nas regiões Sul e Sudeste (Romão 2011, BFG 2015). No PEIB, são registradas 10 espécies ocorrendo principalmente em campo rupestre, sendo encontradas também em bordas de floresta nebular e muitas vezes associadas a cursos d'água.

3.1. Gaylussacia amoena Cham., Linnaea 8: 501. 1833.

Subarbusto ou arbusto, 0,6-1,2 $\mathrm{m}$ alt. Tricomas tectores alvos, presentes nos ramos, folhas, raque da inflorescência e flores; tricomas glandulares ausentes; glândulas clavadas ou capitadas, rubras a nigrescentes, presentes nos ramos, folhas, inflorescências e flores. Folhas subcoriáceas, elípticas a obovadas ou oblanceoladas, 1,3-3,1 x 0,7-1,5 cm, ambas as faces glabras ou esparsamente pubescentes a hirsutilas apenas na base da nervura central e próximo das margens, com glândulas principalmente na face inferior; base aguda; margem plana ou ligeiramente revoluta, serrilhada ou crenada próximo do ápice; ápice arredondado a obtuso, mucronulado; pecíolo 1-2 $\mathrm{mm}$ compr., rígido. Inflorescência racemosa, axilar; raque $2,4-3,3 \mathrm{~cm}$ compr., tomentela a hirsutila, glandulosa; bráctea floral oblanceolada ou elíptica a rômbica, 3-5 mm compr., esparsamente tomentosa ou apenas ciliada, glandulosa, geralmente com glândula apical espessoalongada; bractéolas estreitamente elípticas ou linearoblanceoladas, 2-4 $\mathrm{mm}$ compr., tomentosas ou ciliadas como as brácteas. Pedicelo 3-4 mm compr.; cálice pubescente a esparsamente hirsutilo nos bordos dos lobos, glanduloso nos bordos dos lobos, ápice desprovido de glândula apical; corola branca ou rosada, campanulada ou tubuloso-campanulada, raramente tubuloso-urceolada, 5-6 $\mathrm{mm}$ compr., externamente glabra; filete ca. $2 \mathrm{~mm}$ compr., dorso glabro ou pubérulo a pubescente, antera 3-3,5 mm compr.; hipanto glabro, glanduloso. Nuculânio verde ou rosado, depresso-globoso, 3-5 mm diâm., glabro.

Material examinado: Lima Duarte. Parque Estadual do Ibitipoca. XII.2000, fl. e fr., F.R.G. Salimena s.n. (CESJ 32702). Ponte de Pedra, IX.1987, fl., M. Sobral et al. 5604 (ICN). Trilha para a Janela do Céu, proximidades da Gruta da Cruz, 15.XI.2014, fl. e fr., G.O. Romão \& A.P.T. Dantas 3498 (ESA). Serra de Ibitipoca, 29.IX.1970, fl., U. Confúcio s.n. (CESJ 9350). Idem, XI.1847, fl., Hellages 2272 (R). Idem, 30.IX.1970, fl., L. Krieger s.n. (CESJ 9395a). Idem, sem data, fl., L. Krieger s.n. (CESJ 9377).

Gaylussacia amoena assemelha-se a $G$. brasiliensis, que também ocorre no PEIB, no aspecto geral dos ramos $\mathrm{e}$ folhas, mas que diferem-se principalmente quanto ao formato e coloração da corola. Gaylussacia amoena apresenta corola comumente campanulada a tubuloso-campanulada e branca a rosada, enquanto que $G$. brasiliensis possui corola urceolada e mais frequentemente vermelha. Essa espécie distribui-se pelas áreas de maior altitude no domínio da Floresta Atlântica, desde o Rio de Janeiro até o Paraná e pela na Zona da Mata mineira (Romão 2011, BFG 2015). No PEIB foi encontrada em áreas de campo rupestre e coletada com flores em setembro, novembro e dezembro, e com frutos em novembro e dezembro. (2011).

Ilustrações em Silva \& Cervi (2006) e Romão

3.2. Gaylussacia brasiliensis (Spreng.) Meisn. in Mart. \& Eichler var. brasiliensis, FI. bras. 7: 144. 1863.

Subarbusto a arbusto, 1-2 $\mathrm{m}$ alt. Tricomas tectores alvos, presentes nos ramos, folhas, raque da inflorescência, flores e frutos; tricomas glandulares ausentes; glândulas clavadas, rubras a nigrescentes, presentes nos ramos, folhas, inflorescência, flores e frutos. Folhas subcoriáceas a coriáceas, elípticas a oblongas ou obovadas a oblanceoladas, 2,2-5,1 x 0,9$1,8 \mathrm{~cm}$, face adaxial glabra ou esparsamente pubescente na nervura principal, face abaxial glabra a densamente pubescente ou setulosa apenas na nervura principal ou em todo o limbo, glandulosas principalmente na face abaxial; base arredondada a aguda, margem plana, serrilhada próximo do ápice, 
ápice arredondado a obtuso, mucronulado; pecíolo 1-5 $\mathrm{mm}$ compr., rígido. Inflorescência racemosa ou paniculada, axilar; raque 1,9-4,8 cm compr., glabra ou pubescente a tomentosa, glandulosa; bráctea floral foliácea, ovalada a obovada, 3-5 mm compr., pubescente a vilosa ou apenas ciliada, com glândula apical espesso-deltóide; bractéolas linear-setiformes, 1-5 mm compr., glabras a pubescentes e glandulosas como as brácteas. Pedicelo 4-6 mm compr.; cálice glabro a pubescente ou apenas ciliado, glanduloso, ápice desprovido de glândula apical; corola rosada ou vermelha, urceolada, 6-12 $\mathrm{mm}$ compr., externamente glabra ou pubescente nos ângulos; filete 1-4 mm compr., dorso pubérulo a tomentoso, antera 1,5-3 mm compr.; hipanto glabro ou pubescente a viloso. Nuculânio verde, negro, vináceo ou rosado, depressogloboso a depresso-ovóide, 3-5 mm diâm., glabro ou pubescente, glanduloso.

Material examinado: Lima Duarte. Parque Estadual do Ibitipoca. 19.VI.1991, fl. e fr., M. Brugger s.n. (CESJ 25321). Ao lado do prédio da administração, 18.VIII.2004, fr., R. Tsuji et al. 466a (ESA, HPL). Ca. $500 \mathrm{~m}$ da lanchonete em

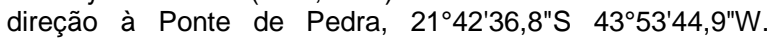
18.VIII.2004, fl., R. Tsuji \& G.O. Romão 458 e 465 (ESA, HPL). Próximo à Gruta do Monjolinho, 12.IX.1991, fl., S.M.S. Verardo s.n. (CESJ 25368, UEC 58515). Próximo à Ponte de Pedra, 23.Il.1992, fr., M. Eiterer \& G. Freitas s.n. (CESJ 125814, MBM 277092). Serra de Ibitipoca, 29.IX.1970, fl., U.C. Câmara s.n. (CESJ 9350, UEC 74965).

Gaylussacia brasiliensis é a espécie de Ericaceae mais amplamente distribuída no Brasil, ocorrendo desde a zona costeira até as cadeias montanhosas do Centro-Oeste, e ocorre em diversos hábitats, desde campos de altitude, em áreas não alagáveis até constantemente úmidas, matas ciliares e restingas. Assim, é a espécie que mais apresenta variações no formato, tamanho e indumento das folhas (Romão 2011, BFG 2015). No aspecto geral da planta, essa espécie assemelha-se a outra que também ocorre no PEIB, G. rhododendron, porém diferem quanto à presença de tricomas glandulares. Gaylussacia brasiliensis não possui qualquer tricoma glandular nos ramos e folhas, enquanto que $G$. rhododendron apresenta ramos e nervura principal das folhas híspido-glandulares. No PEIB foi encontrada em áreas de campo rupestre e coletada com flores em junho, agosto e setembro, e com frutos em fevereiro, junho e agosto.

llustrações em Marques (1975), Silva \& Cervi (2006), Kinoshita-Gouvêa (1980), Romão (2011) e Kinoshita \& Romão (2012).

3.3. Gaylussacia chamissonis Meisn. in Mart. \& Eichler, FI. bras. 7: 144. 1863.

Arbusto, 0,25-0,6 $\mathrm{m}$ alt. Tricomas tectores alvos, presentes nas folhas, raque da inflorescência, flores e frutos; tricomas glandulares ausentes; glândulas capitadas, amareladas, presentes nas folhas, raque da inflorescência, flores e frutos. Folhas subcoriáceas, oblanceoladas a elípticas, 0,5-2,5 x 0,2$0,7 \mathrm{~cm}$, esparsamente pubescentes em ambas as faces, mais densamente na nervura central da face abaxial, glandulosas em ambas as faces, base aguda a cuneada, margem levemente a fortemente revoluta, inteira, ápice cuneado a arredondado, mucronado; pecíolo 1-1,5 mm compr., rígido. Inflorescência racemosa, axilar; raque 1,2-3,5 cm compr., esparsamente pubescente, glandulosa; bráctea floral largo-elíptica, 3-3,5 mm compr., esparsamente pubescente, glandulosa; bractéolas estreito-elípticas, 2,2-2,3 mm compr., esparsamente pubescentes, mais densamente próximo à margem, glandulosas. Pedicelo 1,8-3 mm compr.; cálice 1,4-1,7 mm compr., externamente esparsamente pubescente, densamente próximo à margem e ao hipanto, glanduloso, ápice desprovido de glândula apical; corola alva, campanulada, 5-6 mm compr., externamente esparsamente pubescente nos ângulos; filete 1,8-2,3 $\mathrm{mm}$ compr., dorso tomentoso, glanduloso, antera 1,9-3 $\mathrm{mm}$ compr.; hipanto densamente pubescente, glanduloso. Nuculânio verde, depresso-globoso, 3-5 $\mathrm{mm}$ diâm., esparsamente pubescente, glanduloso.

Material examinado: Lima Duarte. Parque Estadual do Ibitipoca. III.1996, st., L.G. Rodela s.n. (CESJ 31445). Caminho para a Lagoa Seca, 18.X.2003, fl. e fr., R.C. Forzza et al. 2446 (CESJ, ESA, RB). Próximo à diretoria, 5.XII.1992, fl. e fr., R.C. Oliveira et al. 105 (CESJ, ESA). Próximo à portaria, 1.XI.2014, fl., A. Cabral et al. 98 (CESJ). Subida das Bromélias, 16.XII.2007, fl., F.R.G. Salimena et al. 985 (CESJ). Trilha da Prainha para o Monjolinho, 28.X.2004, fl., R.C. Forzza et al. 3594 (CESJ, ESA, RB). Trilha para Janela do Céu, proximidades da Gruta da Cruz, 15.XI.2014, fl., G.O. Romão \& A.P.T. Dantas 3499 (ESA). Serra de Ibitipoca, 3.XI.1973, fl., L. Krieger s.n. (CESJ 13229, UEC 59015).

Gaylussacia chamissonis pode ser facilmente diferenciada das demais espécies do gênero através de caracteres vegetativos, como as folhas com margem fortemente revoluta, com indumento setoso e glândulas capitado-amareladas em ambas as faces (Romão 2011). É endêmica da Região Sudeste do Brasil, ocorrendo em Minas Gerais, Rio de Janeiro e São Paulo (BFG 2015). PEIB foi encontrada em áreas de campo rupestre e coletada com flores nos meses de outubro a dezembro, e com frutos em novembro e dezembro.

Ilustrações em Romão (2011), Kinoshita \& Romão (2012), Mezabarba et al. (2013) e Cabral et al. (2016b).

3.4. Gaylussacia decipiens Cham., Linnaea 8: 500. 1833.

Fig. $2 \mathrm{H}$

Arbusto, 0,25-0,6 $\mathrm{m}$ alt. Tricomas tectores alvos, presentes nos ramos, folhas, raque da inflorescência, flores e frutos; tricomas glandulares ausentes; glândulas clavadas, rubro-nigrescentes, presentes nas folhas, raque da inflorescência e flores. Folhas subcoriáceas a coriáceas, oblanceoladas, 
largo-oblanceoladas e elípticas, 0,8-4,1 x 0,3-1,5(-1,8) $\mathrm{cm}$, glabras em ambas as faces, frequentemente pubescentes na porção basal da face adaxial, glandulosas na face abaxial, base aguda a cuneada, margem plana a revoluta, crenado-denteada próximo ao ápice, ápice agudo a arredondado, mucronado; pecíolo 2-3,5 $\mathrm{mm}$ compr., rígido. Inflorescência racemosa, axilar; raque 1,8-5,5 cm compr., esparsa a densamente pubescente, glandulosa; bráctea floral ovada a largo-elíptica, 3,5-5 mm compr., ciliada e pubescente na porção basal, frequentemente glandulosa na margem, desprovida de glândula apical espessa; bractéolas estreito-lanceoladas, 2,2-2,5 mm compr., indumento como na bráctea. Pedicelo 2-2,5 $\mathrm{mm}$ compr.; cálice 1-1,2 mm compr., ciliado, glanduloso, ápice desprovido de glândula apical; corola alva, campanulada a largo-campanulada, 5-8 $\mathrm{mm}$ compr., externamente glabra; filete 1,2-2,5 mm compr., ciliado ou com dorso tomentoso na porção apical, antera 2,8-3 mm compr.; hipanto glabro a esparsamente pubescente, frequentemente glanduloso. Nuculânio verde a verde-avermelhado, globoso, ca. $3 \mathrm{~mm}$ diâm., esparsamente pubescente.

Material examinado: Conceição de Ibitipoca. Parque Estadual de Ibitipoca. 19.VI.1991, fl., M. Brugger s.n. (CESJ 25309). Atalho do Pião, 2.XI.1991, fl. e fr., R.C. Oliveira 39 (CESJ). Caminho para o Monjolinho, 12.IX.1991, fl., S.M.S. Verardo et al. s.n. (CESJ 25381, UEC 74955). Trilha para Cachoeirinha, 21 $40^{\prime} 17^{\prime \prime S} 43^{\circ} 52^{\prime} 24^{\prime \prime W}$, 27.IX.2001, fl. e fr., R. Marquete et al. 3100 (RB). Idem, 18.VIII.2004, st., R. Tsuji et al. 466b (HPL). Trilha para Janela do Céu, proximidades da Gruta da Cruz, 15.XI.2014, fl. e fr., G.O. Romão \& A.P.T. Dantas 3496 (ESA). Caminho para a Lagoa Seca saindo do Pião, 31.III.2004, fl., E.S. Medeiros et al. 339 (RB). Caminho para o Pico do Pião, 18.X.2003, fl., R.C. Forzza et al. 2441 (ESA, RB). Próximo à Gruta dos Coelhos, 31.X.2014, fr., A. Cabral et al. 92 (CESJ). Próximo à Lombada, 6.VIII.2014, fl., A. Cabral et al. 88 (CESJ). Próximo à portaria, 1.XI.2014, fl., $A$. Cabral et al. 97 (CESJ); 1.XI.2014, fr., A. Cabral et al. 99 (CESJ). Próximo ao Lago das Miragens, 1.XI.2014, fl. e fr., A. Cabral et al. 95 (CESJ). Subida para o Monjolinho, 16.XII.2001, fl. e fr., F.R.G. Salimena et al. 986 (CESJ). Trilha para Gruta do Viajante, 31.VIII.2004, fl., M.M. Saavedra et al. 207 (ESA, RB). Entre Monjolinho e Lagoa Seca, 28.VIII.1993, fl., F.R.G. Salimena et al. s.n. (CESJ 26778). Serra de Ibitipoca, IX.1970, fl., P.I.S. Braga et al. 1914 (NCU, RB). Idem, 27.VII.1970, fl. e fr., L. Krieger s.n. (CESJ 9252, RB 397903). Idem, 3.XI.1973, fl., L. Krieger s.n. (CESJ 13235, UEC 50025). Idem, 19.IX.1940, fl., M. Magalhães 529 (ICN). Idem, 30.IX.1970, fl., D. Sucre et al. 7216 (F, M, MICH, MO, NY, RB, UEC, US). Idem, 1.X.1970, fl., U.C. Câmara s.n. (CESJ 9464, RB 151346).

Gaylussacia decipiens é caracterizada por apresentar folhas maduras rigidamente coriáceas, com face adaxial lisa e lustrosa, geralmente glabras ou hirsútulas na base, e corola cilíndrica a campanulada (Romão 2011). Glândulas apenas nos bordos do cálice ocorrem somente nas populações de lbitipoca e Ouro Preto, Minas Gerais, em contraste com as demais populações da espécie, com glândulas distribuídas por toda a superfície externa do cálice (Romão 2011). É endêmica de Minas Gerais, Rio de Janeiro e São Paulo (BFG 2015). No PEIB ocorre em campo rupestre e próxima a cursos d'água, onde floresce de maio a dezembro e frutifica em julho e de setembro a dezembro.

llustrações em Meisner (1863), KinoshitaGouvêa (1980), Romão (2011), Kinoshita \& Romão (2012), Mezabarba et al. (2013) e Cabral et al. (2016b).

3.5. Gaylussacia densa Cham., Linnaea 8: 496. 1833.

Arbusto, ca. $1 \mathrm{~m}$ alt. Tricomas tectores alvos, presentes nos ramos, folhas, raque da inflorescência, flores e frutos; tricomas glandulares ausentes; glândulas clavadas a pediceladas, amareladas a rubro-nigrescentes, presentes nos ramos, folhas, raque da inflorescência, flores e frutos. Folhas subcoriáceas, elípticas, levemente ovadas a obovadas, 1-3,7 x 0,5-1,8 cm, esparsamente pubescentes, densamente na nervura principal de ambas as faces, glandulosas na face abaxial, base aguda a obtusa, margem levemente revoluta próximo à base, inteira, ápice obtuso a arredondado, mucronulado; pecíolo 1,5 a $3 \mathrm{~mm}$ compr., rígido. Inflorescência racemosa, axilar ou terminal; raque 1,8-4 cm compr., esparsamente pubescente, glandulosa; bráctea floral oval, 6,5-7 mm compr., pubescente, glandulosa; bractéolas lineares a lanceoladas, 3,5-4 mm compr., indumento como na bráctea. Pedicelo 2-3 mm compr.; cálice 1,5-1,8 mm compr., externamente pubescente, glanduloso, ápice desprovido de glândula apical; corola alva, urceolada a estreito-campanulada, 4,8-7 mm compr., externamente pubescente, glandulosa; filete ca. $2 \mathrm{~mm}$ compr., dorso pubescente, antera ca. $2 \mathrm{~mm}$ compr.; hipanto densamente pubescente, glanduloso. Nuculânio verde a verde-arroxeado, depresso-globoso, 3,5-4 mm diâm. pubescente.

Gaylussacia densa é muito variável no tamanho das folhas e indumento geral da planta (Romão 2011). Sleumer (1967) e Kinoshita \& Romão (2012) reconhecem três variedades com base no tamanho da corola e indumento dos ramos, folhas e flores, das quais duas ocorrem no PEIB.

\subsubsection{Gaylussacia densa Cham. var. densa}

Gaylussacia densa var. densa é endêmica do Brasil, ocorrendo nos domínios do Cerrado e Floresta Atlântica, da Bahia a São Paulo (BFG 2015). No PEIB é encontrada em campo rupestre e em borda de floresta nebular e coletada com flores em março, junho e agosto e com frutos em março.

Material examinado: Lima Duarte. Parque Estadual do Ibitipoca. 23.III.1995, fl., A.E. Luchi et al. 429 (SP). 25.III.2001, fr., R.M. Castro et al. 221 (CESJ). Na metade do caminho entre a portaria e a Lombada, 3.VIII.2014, fl., A. Cabral et al. 82 (CESJ). Serra de Ibitipoca, VI.1896, fl., M. Gomes \& H. Magalhães 634 p.p.2 (R). Idem, sem data, fl., A. Saint-Hilaire 237 (L, P). 

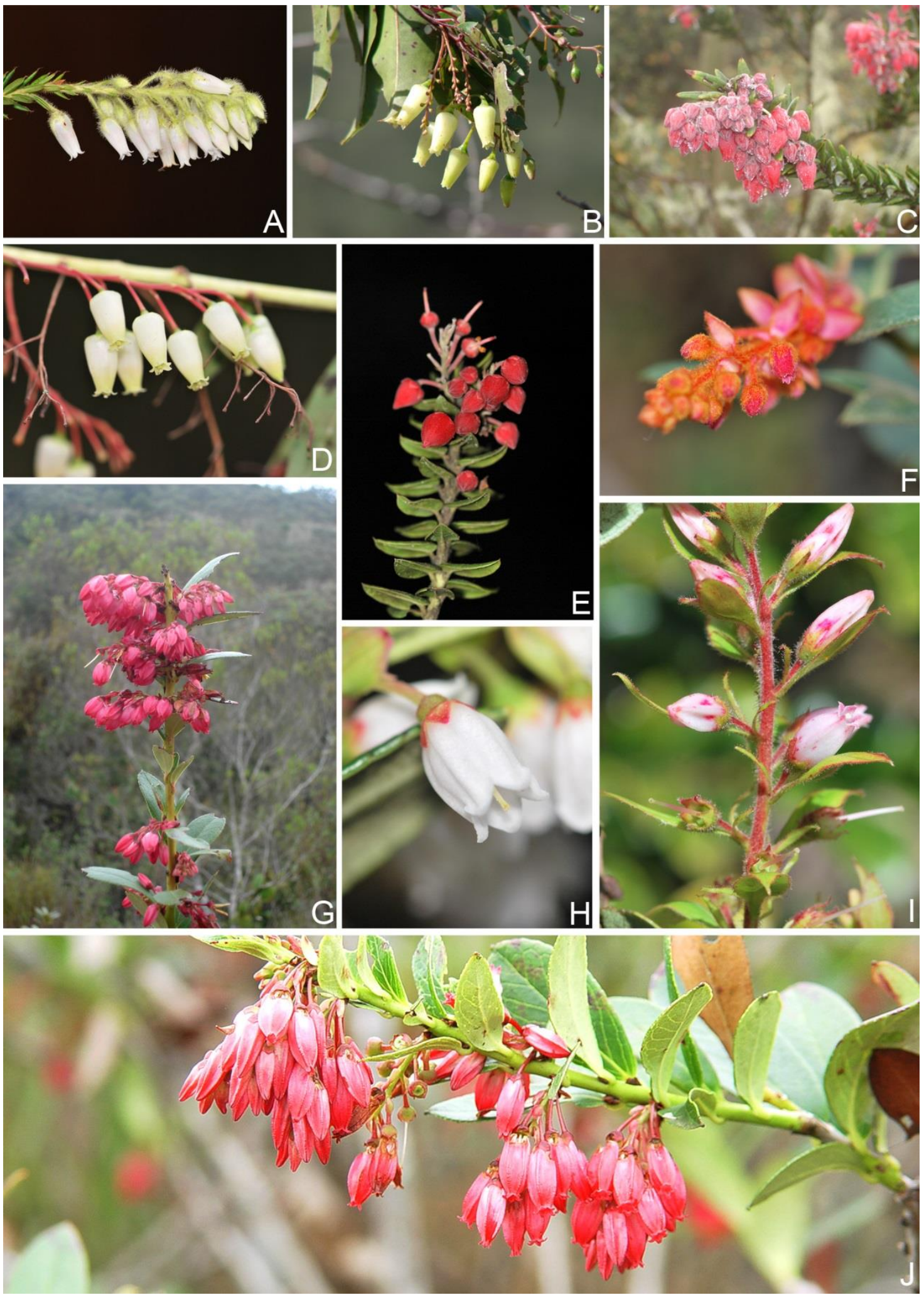

Fig. 2: A. Agarista ericoides. B. Agarista glaberrima. C. Agarista hispidula. D. Agarista oleifolia. E. Agarista pulchella var. cordifolia. F. Gaultheria eriophylla var. eriophylla. G. Gaylussacia brasiliensis var. brasiliensis. H. Gaylussacia decipiens. I. Gaylussacia rhododendron. J. Gaylussacia salicifolia. A, B, E-F, H e I, fotografias de Luiz Menini Neto; C, G e J, fotografias de Mariana Saavedra. 
llustrações em Kinoshita-Gouvêa (1980), Silva \& Cervi (2006), Romão (2011), Kinoshita \& Romão (2012) e Cabral et al. (2016a).

3.5.2. Gaylussacia densa var. oblonga Meisn. in Mart. \& Eichler, FI. bras. 7: 135. 1863.

Fig. 3A

Gaylussacia densa var. oblonga é endêmica do Brasil, ocorrendo nas regiões de maior altitude da Floresta Atlântica em Minas Gerais, Rio de Janeiro e São Paulo até a bacia do Paranaguá no Paraná (Romão 2011; BFG 2015). No PEIB foi encontrada em campo rupestre e coletada com flores nos meses de janeiro e fevereiro e com frutos nos meses de janeiro, fevereiro, maio e agosto.

Material examinado: Lima Duarte. Parque Estadual do Ibitipoca. 22.I.1987, fl. e fr., P.M. Andrade et al. 892 (BHCB, SPF). Bosque entre o Centro de informações e o Camping, 21.V.1999, fr., M.A. Manhães 18 (CESJ). Entrada sentido alojamento, 18.I.2008, fl. e fr., R. Tsuji 2458 (ESA, HPL). Próximo à portaria, 5.VIII.2014, fr., A. Cabral et al. 87 (CESJ). Trilha para a Ponte de Pedra, 23.II.1992, fr., M. Eiterer \& G.S. Freitas 113 (CESJ). Serra do Ibitipoca, 24.II.1977, fl., L. Krieger s.n. (CESJ 14623, MBM 275521).

Romão (2012).

llustrações em Romão (2011) e Kinoshita \&

3.6. Gaylussacia aff. fasciculata Gardn., Lond. J. Bot. 4: 131. 1845.

Subarbusto a arbusto, 0,4-1,7 m alt. Tricomas tectores alvos, presentes nos ramos, folhas, flores e frutos; tricomas glandulares alvos, presentes no cálice e raramente na raque da inflorescência; glândulas clavadas ou capitadas presentes nos ramos, folhas e raque da inflorescência. Folhas subcoriáceas, oblanceoladas ou estreitamente elípticas, (1,9-)2,5-4,5 $x$ 0,7-1,4 cm, marcadamente discolores, ambas as faces pubescentes, mais densamente na abaxial, glandulosas em ambas as faces, base aguda, frequentemente assimétrica, margem ligeiramente revoluta, inteira ou serrilhada próximo ao ápice, ápice arredondado ou agudo, mucronulado; pecíolo 2-5 mm compr., rígido. Inflorescência racemosa, axilar subapical; raque 2,2-5,7 cm compr., pubescente, raramente hispídulo-glandular; bráctea floral folíacea, oblanceolada, 4-8 mm compr., pubescente; bractéolas linear-filiformes,1-3 $\mathrm{mm}$ compr., glabras ou pubescentes. Pedicelo 2-7 mm compr.; cálice ca. 1 $\mathrm{mm}$ compr., esparsamente pubescente, geralmente hispídulo-glandular nos bordos dos lobos, ápice desprovido de glândula apical; corola branca, tubuloso-urceolada, 5-6 mm compr., externamente esparsamente pubescente nos ângulos; filete ca. 1,5 $\mathrm{mm}$ compr., pubescente, antera 2-2,5mm compr.; hipanto densamente pubescente, com glândulas clavadas nigrescentes. Nuculânio castanho, globoso, 3-4mm diâm., pubescente.
Material examinado: Lima Duarte. Parque Estadual da Serra do Ibitipoca. Ao lado da guarita de entrada do Parque, 23.I.2007, fl., R.C. Forzza et al. 4385 (CESJ, K, NY, RB). Entre a Gruta do Viajante e o Pico do Pião, 10.III.2004, fl. e fr., R.C. Forzza et al. 3121 (CESJ, ESA, MBM, RB).

Material adicional examinado: Minas Gerais. Congonhas do Norte, Serra do Cipó, Retiro do Barbado, Rio Preto, $18^{\circ} 52^{\prime} S 43^{\circ} 46^{\prime}$ W, 22.IV.1982, fl. e fr., M.C.E. Amaral et al. CFSC 8421 (ESA, SPF). Jaboticatubas, rodovia Lagoa Santa-Conceição do Mato Dentro-Diamantina Km 127, 7.IX.1974, fl., J. Semir et al. CFSC 5168 (ESA, SP, UEC).

Gaylussacia aff. fasciculata será descrita como nova para a ciência por Romão et al. (em prep.), e assemelha-se a $G$. fasciculata por apresentar râmulos e folhas pubescentes e com glândulas nigrescentes, folhas subcoriáceas e marcadamente discolores, corola branca e comparativamente pequena, de até $6 \mathrm{~mm}$ de comprimento. Diferem quanto ao indumento das folhas, com face abaxial glabra a esparsamente pubescente na nervura central, e do cálice, apenas com tricomas tectores em $G$. fasciculata (Romão 2011), enquanto que $G$. aff. fasciculata tem as folhas densamente pubescentes por toda a face abaxial e o cálice possui tricomas tectores e glandulares. Gaylussacia aff. fasciculata ocorre somente no estado de Minas Gerais, na Serra do Ibitipoca e em áreas da Cadeia do Espinhaço, principalmente na Serra do Cipó (Romão 2011). No PEIB foi encontrada em áreas de borda de floresta nebular adjacentes aos campos rupestres, e coletada com flores nos meses de janeiro e março, e com frutos em março.

3.7. Gaylussacia pseudogaultheria Cham. \& Schltdl., Linnaea 1: 535. 1826.

Fig. 3B

Arbusto, ca. 0,4 $\mathrm{m}$ alt. Tricomas tectores alvos, presentes nos ramos, folhas, raque da inflorescência e flores; tricomas glandulares presentes nos ramos, folhas, raque da inflorescência, flores e frutos; glândulas capitadas, rubro-amareladas, presentes nas folhas, raque da inflorescência e flores. Folhas concolores, cartáceas a subcoriáceas, estreitooblongas, oblongas a ovadas, às vezes obovadas, 1-3 $x$ 0,4-1,1 cm, pubescentes na nervura central e na margem da face adaxial, glabras a pubescentes próximo à base na nervura central da face abaxial, híspido-glandulares em ambas as faces, glandulosas na face abaxial, base subcordada a arredondada, margem levemente revoluta, inteira, ápice agudo a arredondado, mucronulado; pecíolo 1-1,2 mm compr., rígido. Inflorescência racemosa, axilar; raque ca. 1,2 $\mathrm{cm}$ compr., tomentosa, densamente híspido-glandular, glandulosa; bráctea floral largo-lanceolada, 5-6 mm compr., esparsamente pubescente, híspido-glandular e glandular; bractéolas estreito-elípticas a lanceoladas, 3,5-4 mm compr., indumento como na bráctea. Pedicelo 1,8-4 mm compr.; cálice 1,5-1,8 mm compr., ciliado e densamente híspido-glandular nos bordos dos lobos e próximo ao hipanto, ápice desprovido de 
glândula apical; corola alva, campanulada, 5,5-7 mm compr., externamente esparsamente híspido-glandular nos ângulos; filete 2-2,2 mm compr., dorso pubescente e híspido-glandular, antera 3,2-3,5 mm compr.; hipanto densamente híspido-glandular. Nuculânio verde, depresso-globoso, 4-6 mm diâm., esparsamente híspido-glandular.

Material examinado: No caminho entre a Lombada e a Gruta do Monjolinho, 2.XI.2014, fl., A. Cabral et al. 103 (CESJ).

Material adicional examinado: MINAS GERAIS. Baependi: Parque Estadual da Serra do Papagaio, Serra do Cambuí, borda de mata de araucária, 12.Il.2013, fr., $A$. Cabral et al. 50 (CESJ, ESA).

Gaylussacia pseugaultheria pode ser distinta das demais espécies do gênero por ocorrer frequentemente sobre solos alagáveis, além de possuir ramos, folhas e flores densamente híspidoglandulares e corola alva (Romão 2011). É endêmica do Brasil, ocorrendo no Cerrado e Floresta Atlântica, desde a Bahia até o Rio Grande do Sul (BFG 2015). No PEIB foi encontrada em áreas de campo rupestre, e coletada com flores em novembro.

llustrações em Meisner (1863, sob $G$. hispida), Marques (1975), Silva \& Cervi (2006), Romão (2011) e Kinoshita \& Romão (2012) e Cabral et al. (2016b).

3.8. Gaylussacia rhododendron Cham. \& Schltdl., Linnaea 1: 533. 1826.

Fig. 2I, 3C

Arbusto, ca. $2 \mathrm{~m}$ alt. Tricomas tectores alvos a acinzentados, presentes nos ramos, folhas, raque da inflorescência, flores e frutos; tricomas glandulares presentes nas folhas, raque da inflorescência, flores e frutos; glândulas clavadas, rubro-nigrescentes, presentes nas folhas e flores. Folhas subcoriáceas a coriáceas, folhas jovens frequentemente cartáceas, elípticas a largo-elípticas, raramente ovadas, 1,7-5,1 x 0,7-2,45 cm, esparsamente pubescentes na nervura central, mais densamente na porção basal na face adaxial, híspido-glandulares em ambas as faces, mais densamente na face abaxial, glandulosas em ambas as faces, base obtusa a arredondada, margem levemente revoluta, levemente serreada, ápice cuneado a arredondado, mucronado; pecíolo 2-4 mm compr., rígido. Inflorescência racemosa, axilar; raque 2,9-7 cm compr., densamente pubescente e híspidoglandular; bráctea floral elíptica, 8-15 mm compr., pubescente e híspido-glandular, mais densamente na margem e próximo a ela; bractéolas lineares a estreito-elípticas, 4-8 mm compr., indumento como na bráctea. Pedicelo 2,5-4 mm compr.; cálice 2-3 mm compr., pubescente e híspido-glandular, mais densamente na margem dos lobos e próximo à ela, ápice desprovido de glândula apical; corola rósea, urceolada, 7-8 mm compr., externamente glabra; filete
3-4 mm compr., dorso pubescente, antera 3,3-4,2 mm compr.; hipanto densamente híspido-glandular, glanduloso. Nuculânio verde quando imaturo, depresso-globoso a globoso, ca. 4,6 mm diâm., esparsamente híspido-glandular.

Material examinado: Lima Duarte. Parque Estadual do Ibitipoca. Alto do Pião, 19.IX.1940, fl., M. Magalhães 445 (BHCB, MBM). Entre o Cruzeiro e a Lombada, 5.IX.2014, fl., C. Nardy et al. 34 (CESJ). Próximo ao Pico do Pião, 2.VIII.2014, fl. e fr., A. Cabral et al. 78 (CESJ), 5.IX.2014, fl. C. Nardy et al. 31 (CESJ).

Gaylussacia rhododendron distingue-se facilmente das demais espécies do gênero pelas folhas cartáceas a subcoriáceas, com tricomas glandulares estreito-alongados, alvos, com 1-2 mm compr., além da corola urceolada, rosada a branca (Romão 2011). Gaylussacia rhododendron é endêmica do Domínio Atlântico de Minas Gerais, Rio de Janeiro e São Paulo (Romão 2011; BFG 2015). No PEIB ocorre em áreas de campo rupestre, e foi coletada com flores agosto e setembro, e com frutos em agosto. Ilustrações em Meisner (1963), Silva \& Cervi (2006), Takeuchi \& Afonso (2009), Kinoshita \& Romão (2012) e Cabral et al. (2016a).

3.9. Gaylussacia riedelii Meisn. in Mart. \& Eichler, FI. bras. 7: 139, t. 52. 1863.

Fig. 3D-E

Subarbusto a arbusto, 0,2-1 $\mathrm{m}$ alt. Tricomas tectores alvos, presentes nas folhas e flores; tricomas glandulares ausentes; glândulas clavadas a pediceladas, rubro-nigrescentes, presentes nas folhas, raque da inflorescência e flores. Folhas rigidamente coriáceas, folhas jovens frequentemente cartáceas, obovadas, ovadas e largo-elípticas, 2,2-4,4 x 0,9-2 cm, glabras, frequentemente glandulosas em ambas as faces, base obtusa a arredondada, margem plana, inteira a levemente crenulada na porção apical, ápice agudo a arredondado, mucronado; pecíolo 2,5-4 mm compr., rígido. Inflorescência racemosa, axilar; raque 2,7-6,5 cm compr., glabra, frequentemente glandulosa; bráctea floral rômbica a elíptica, 4,2-6 mm compr., glabra, glandulosa na margem; bractéolas lineares, 34,5 mm compr., indumento como na bráctea. Pedicelo 5-8 mm compr.; cálice 1,5-2 mm compr., externamente glabro, frequentemente glanduloso, com glândula apical espessa; corola rósea, tubuloso-campanulada a campanulada, 6-9 mm compr., externamente glabra; filete 2,6-3,7 mm compr., dorso tomentoso, antera 4,8$5,5 \mathrm{~mm}$ compr.; hipanto glabro, frequentemente glanduloso. Nuculânio negro, depresso-globoso, ca.5 mm diâm., glabro.

Material examinado: Serra de Ibitipoca, 24.IV.1957, fl. e fr., E. Pereira 3200 (HB, L, RB, UEC). Idem, Pico do Pião, 11.VIII.1876, fl. e fr., C.A.W. Schwacke 12342bis (C, L, RB, UEC). 


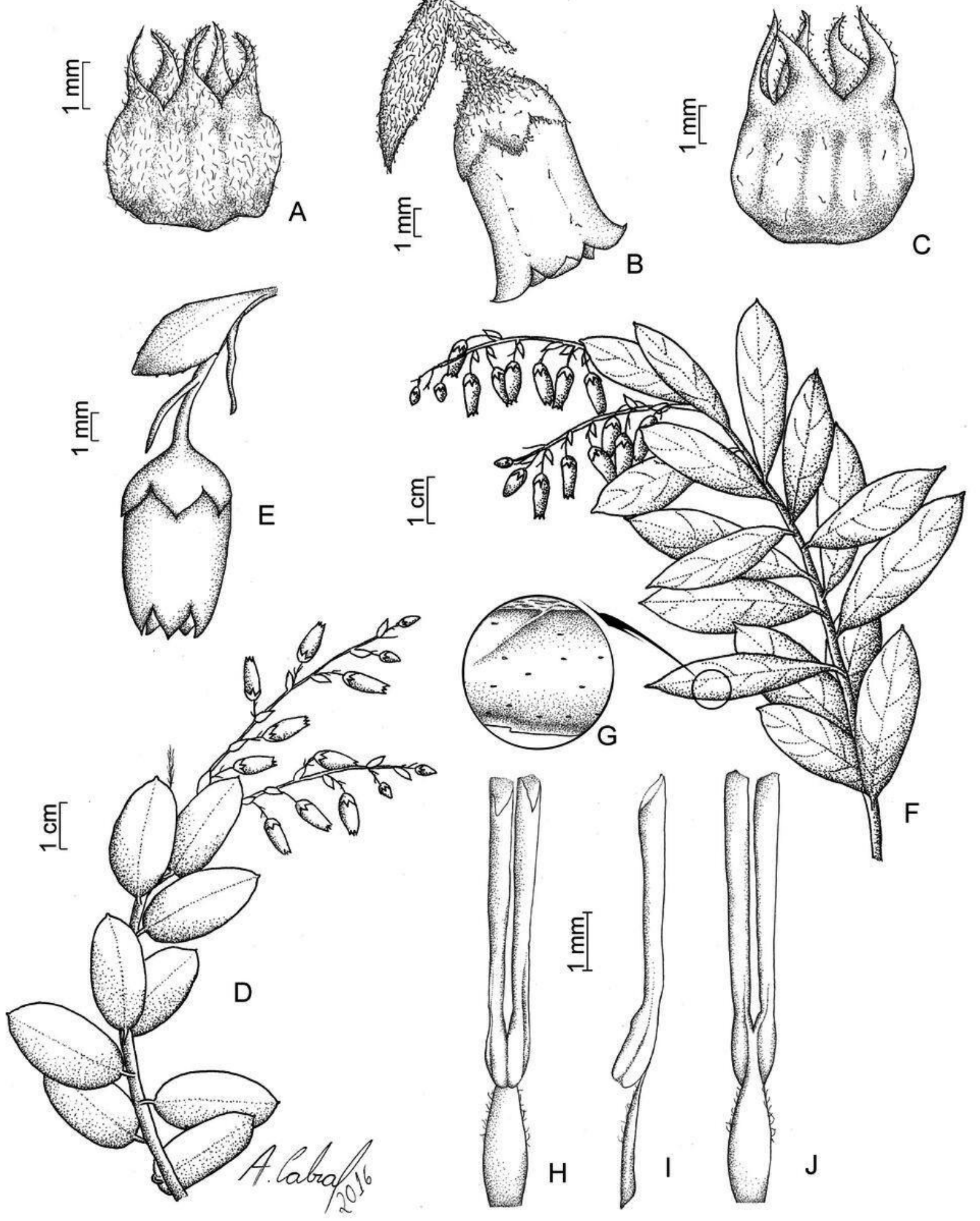

Fig. 3: A. Gaylussacia densa var. oblonga, nuculânio imaturo (Cabral 87). B. Gaylussacia pseudogaultheria, vista geral da flor, bráctea e uma das bractéolas (Cabral 103). C. Gaylussacia rhododendron, nuculânio imaturo (Cabral 78). D-E. Gaylussacia riedelii, D. ramo florido, E. vista geral da flor, bráctea e bractéolas (Schwacke 12342bis). F-J. Gaylussacia salicifolia, F. ramo florido, G. detalhe do indumento da folha, H. vista ventral do estame, C. vista lateral do estame, D. vista dorsal do estame (Verardo 25372). 
Gaylussacia riedelii é facilmente distinta das demais espécies do gênero por apresentar ramos glabros ou subglabros, folhas rigidamente coriáceas, com a face abaxial geralmente avermelhada e cálice com glândula apical espessa (Romão 2011). No presente trabalho, os limites da distribuição geográfica deste táxon foram ampliados para os domínios da Floresta Atlântica, pois até então era registrada para a Serra do Cipó e Planalto de Diamantina, porção central da Cadeia do Espinhaço (Romão \& Souza 2014; BFG 2015). Esta espécie foi pouco coletada em Ibitipoca, a última vez em 1957, quando ainda não havia a Unidade de Conservação, podendo ter sido extinta localmente. No PEIB foi coletada com flores e frutos em abril e agosto. Souza (2014).

llustrações em Meisner (1863) e Romão \&

3.10. Gaylussacia salicifolia Cham. \& Schltdl., Linnaea 1: 532. 1826.

Fig. 2J, 3F-J

Arbusto, 1-4 m alt. Tricomas tectores alvos, presentes na raque da inflorescência e flores; tricomas glandulares ausentes; glândulas clavadas, rubronigrescentes, presentes nas folhas, raque da inflorescência e flores. Folhas subcoriáceas, estreito a largo-elípticas e oblanceoladas, (1,2-)1,8-6 x (0,5-)0,7$2,2 \mathrm{~cm}$, glabras, glandulosas em ambas as faces, frequentemente apenas na face abaxial, base cuneada a arredondada, margem plana, levemente crenulada, ápice agudo a arredondado, mucronado; pecíolo 2-4,5 $\mathrm{mm}$ compr., rígido. Inflorescência racemosa, axilar; raque 1,5-3 cm compr., glabra, frequentemente glandulosa; bráctea floral rômbica a ovada, 5,3-8,5 $\mathrm{mm}$ compr., ciliada, desprovida de glândula apical espessa; bractéolas lineares, 2,2-3,5 mm compr., glabras ou ciliadas. Pedicelo 6-10 mm compr.; cálice 1,2-2 mm compr., glabro, ápice desprovido de glândula apical; corola róseo-avermelhada, urceolada, 9-12 mm compr., externamente glabra; filete 2,8-3 mm compr., ciliado na porção apical, antera 4,5-7,2 mm compr.; hipanto glabro, frequentemente glanduloso. Nuculânio negro a vináceo, globoso, 4,5-7 mm diâm., glabro.

Material examinado: Lima Duarte. Parque Estadual do Ibitipoca. 8.IX.1994, fl., F.R.G. Salimena et al. s.n. (CESJ 27547). Em direção à Gruta do Monjolinho, 15.XI.2014, fl. e fr., G.O. Romão \& A.P.T. Dantas 3497 (ESA). Perto do Lago dos Espelhos, 12.IX.1991, fl., S.M.S. Verardo et al. s.n. (CESJ 25372, UEC 74964). Trilha para o Pião, 2.X.1991, fl. e fr., R.C. Oliveira 40 (CESJ). Prainha, 30.XI.1991, fl. e fr., R.C. Forzza et al. s.n. (CESJ 25696). Cachoeira das Elfas, 1.XI.2014, fl. e fr., A. Cabral et al. 100 (CESJ). Gruta do Monjolinho, 19.X.2003, fl., R.F. Monteiro et al. 5 (CESJ, RB). Mata da Gruta do Monjolinho, 18.I.2005, fr., R.C. Forzza et al. 3931 (CESJ, ESA, RB). Monjolinho, 19.IX.1940, fl., $M$. Magalhães 448 (IAN). Próximo ao Lagos das Miragens, 4.VIII.2014, fr., A. Cabral et al. 83 (CESJ). Idem, 1.XI.2014, fl. e fr., A. Cabral et al. 96 (CESJ). Trilha para a Gruta do Viajante, 31.VIII.2004, fl., M.M. Saavedra et al. 194 (ESA, RB). Trilha para o Monjolinho, 25.VII.2004, fl., R.C. Forzza et al. 3498 (CESJ, ESA, RB). Próximo ao Monjolinho, IX.1999, fl., M.S. Manhães 42 (CESJ). Serra do Ibitipoca, 1.XI.1970, fl. e fr., L. Krieger s.n. (CESJ 9462, UEC 74962).

Gaylussacia salicifolia possui maior semelhança, no PEIB, com G. decipiens, pelos aspectos vegetativos como folhas glabras com margem frequentemente plana, elípticas e oblanceoladas, e subcoriáceas a coriáceas. Gaylussacia salicifolia pode ser diferenciada pela presença de ramos e pedicelos glabros, corola róseoavermelhada, urceolada, e fruto negro, enquanto $G$. decipiens possui ramos pubescentes, pedicelo pubescente, corola alva, campanulada e fruto verde a verde-avermelhado. É endêmica das áreas de maiores altitude de Minas Gerais (BFG 2015). No PEIB é frequentemente encontrada em áreas próximas a cursos d'água, ocorrendo também em campo rupestre e em borda de floresta nebular, onde floresce de julho a novembro, e frutifica em agosto, outubro, novembro e janeiro.

llustrações em Meisner (1863), Romão (2011), Romão \& Souza (2014) e Cabral et al. (2016b).

\section{Agradecimentos}

Agradecemos ao Instituto Estadual de Florestas pelas licenças de coleta e apoio logístico no Parque Estadual do Ibitipoca, ao Programa de PósGraduação em Ecologia da Universidade Federal de Juiz de Fora, pelo apoio logístico de transporte ao Parque, e aos revisores pelas contribuições ao manuscrito.

\section{Referências}

BFG. 2015. Growing knowledge: an overview of Seed Plant diversity in Brazil. Rodriguésia 66(4): 1085-1113.

BUSH, C.M., LU, L., FRITSCH, P.W., LI, D.Z. \& KRON, K.A. 2009. Phylogeny of Gaultherieae (Ericaceae: Vaccinioideae) based on DNA sequence data from matK, ndhF, and nrITS. Int. J. Pl. Sci. 170: 355-364.

CABRAL, A., ROMÃO, G.O., ROMAN, S.A. \& MENINI NETO, L. 2016a. Ericaceae da Serra Negra, Minas Gerais, Brasil. Rodriguésia 67(1): 225-236.

CABRAL, A.; ROMÃO, G.O.; SALIMENA, F.R.G. \& MENINI NETO, L. 2016b. Ericaceae do Parque Estadual da Serra do Papagaio, Minas Gerais, Brasil. Bol. Bot. Univ. São Paulo 34: 7-19. 
CETEC. 1983. Diagnóstico ambiental de Minas Gerais. CETEC. Belo Horizonte.

COSTA, C.M.R., HERRMANN, G., MARTINS, C.S., LINS, L.V. \& LAMAS, I.R. 1998. Biodiversidade em Minas Gerais: Um atlas para sua conservação. Fundação Biodiversitas. Belo Horizonte.

DEBLE, L.P., MARCHIORI, J.N.C., \& OLIVEIRADEBLE, A.S. 2014. A família Ericaceae no Bioma Pampa do Rio Grande do Sul. 1-Agarista chlorantha (Cham.) G.Don. Balduinia 39: 15-18.

DRUMMOND, G.M., MARTINS, C.S., MACHADO, A.B.M., SEBAIO, F.A. \& ANTONINI, Y. 2005. Biodiversidade em Minas Gerais, um atlas para sua conservação. Fundação Biodiversitas. Belo Horizonte.

FIDALGO, O. \& BONONI, V.L. 1984. Técnicas de coleta, preservação e herborização de material botânico (Manual n. 4). Instituto de Botânica, São Paulo.

FORZZA, R.C., MENINI NETO, L., SALIMENA, F.R.G. \& ZAPPI, D.C. (orgs.) 2013. Flora do Parque Estadual do Ibitipoca e seu entorno. Editora UFJF. Juiz de Fora.

FRITSCH, P.W., LU, L., BUSH, C.M., CRUZ, B.C., KRON, K.A. \& LI, D.Z. 2011. Phylogenetic analysis of the wintergreen group (Ericaceae) based on six genic regions. Syst. Bot. 36: 990-1003.

GONÇALVES, E.G. \& LORENZI, H. 2007. Morfologia vegetal: organografia e dicionário ilustrado de morfologia das plantas vasculares. Instituto Plantarum. Nova Odessa.

HARRIS, J.G. \& HARRIS, M.W. 2003. Plant identification terminology: an illustrated glossary. 2 ed. Spring Lake Publ. Spring Lake.

INSTITUTO ESTADUAL DE FLORESTAS \& BRANDT MEIO AMBIENTE. 1994. Parque Estadual de Ibitipoca: levantamento dos aspectos históricos e culturais. Belo Horizonte.

JUDD, W.S. 1984. A taxonomic revision of the American species of Agarista (Ericaceae). J. Arnold Arb. 65: 255-342.

JUDD, W.S. 1995. Agarista G. Don. In J.L. Luteyn, W.S. Judd, S.E. Clemants, G.M. Diggs, P.D. Sørensen, J.L. Door \& G.D. Wallace (eds.) Ericaceae - part II. The superior ovaried genera. Fl. Neotrop. Monogr. 66: 295-344.
JUDD, W.S., CAMPBELL, C.S., KELLOGG, E.A., STEVENS, P.F. \& DONOGHUE, M.J. 2008. Plant systematics, a phylogenetic approach. Ed. 3. Sinauer Associates. Sunderland.

KINOSHITA-GOUVÊA, L.S. $1980 . \quad$ Estudos taxonômicos e fitogeográficos da família Ericaceae no Brasil. Tese de Doutorado. Universidade de São Paulo. São Paulo.

KINOSHITA, L.S. 1995. Ericaceae. In B.L. Stannard, Y.B. Harvey \& R.M. Harley (eds.) Flora of the Pico das Almas, Chapada Diamantina-Bahia, Brazil. Royal Botanical Gardens. Kew, p. 291-296.

KINOSHITA, L.S. 1996. Ericaceae. In M.M.R.S. Melo, F. Barros, S.A.C. Chiea, M. Kirizawa, S.L.J. Mendaçolli \& M.G.L. Wanderley (eds.) Flora Fanerogâmica da llha do Cardoso. Instituto de Botânica. São Paulo, vol. 4, p. 15-17.

KINOSHITA, L.S. \& ROMÃO, G.O. 2010. Ericaceae. In R.C. Forzza, J.F.A. Baumgratz, C.E.M. Bicudo, A.A. Carvalho Jr., A. Costa, D.P. Costa, M. Hopkins, P.M. Leitman, L.G. Lohmann, L.C. Maia, G. Martinelli, M. Menezes, M.P. Morim, M.A.N. Coelho, A.L. Peixoto, J.R. Pirani, J. Prado, L.P. Queiroz, V.C. Souza, J.R. Stehmann, L.S. Sylvestre, B.M.T. Walter \& D.C. Zappi (eds.) Catálogo de Plantas e Fungos do Brasil. Andrea Jakobsson Estúdio. Instituto de Pesquisa Jardim Botânico do Rio de Janeiro. Rio de Janeiro, vol. 2, p. 934-937.

KINOSHITA, L.S. \& ROMÃO, G.O. 2011. Ericaceae. In T.B. Cavalcanti \& A.P. Silva (eds.) Flora do Distrito Federal, Brasil. Embrapa Recursos Genéticos e Biotecnologia. Brasília, vol. 9, p. 115-132.

KINOSHITA, L.S. \& ROMÃO, G.O. 2012. Ericaceae. In M.G.L. Wanderley, G.J. Shepherd, T.S. Melhem, A.M. Giulietti \& S.E. Martins (eds.) Flora fanerogâmica do Estado de São Paulo. Instituto de Botânica. São Paulo, vol. 7, p. 151-172.

KÖPPEN, W. 1931. Grundriss der Klimakunde. Walter de Gruyter. Berlin.

LUTEYN, J.L. 1995. Gaultheria Linnaeus. In J.L. Luteyn, W.S. Judd, S.E. Clemants, G.M. Diggs, P.D. Sørensen, J.L. Dorr \& G.D. Wallace (eds) Ericaceae - part II. The superior ovaried genera. Fl. Neotrop. Monogr. 66: 384-488.

MARINERO, F.E.C., MARANHO, L.T. \& HATSCHBACH, G.G. 2007. O gênero Gaultheria L. (Ericaceae) no Estado do Paraná, Brasil. Revta. Bras. Biociências 5: 615-617. 
MARQUES, M.C.M. 1975. Ericáceas. Parte I. In Reitz, R. (ed.). Flora Ilustrada Catarinense. Herbário Barbosa Rodrigues. Itajaí, p. 1-63.

MEISNER, C.F. 1863. Ericaceae. In C.F.P. von Martius \& A.G. Eichler (eds.) Flora brasiliensis. Lipsiae. Frid. Fleischer, vol. 7, p. 119-182.

MENINI NETO, L., ALVES, R.J.V., BARROS, F. \& FORZZA, R.C. 2007. Orchidaceae do Parque Estadual de Ibitipoca, MG, Brasil. Acta bot. bras. 21(3): 687-696.

MENINI NETO, L. \& SALIMENA, F.R.G. 2013. História do Arraial de Conceição de Ibitipoca e a criação do Parque Estadual do Ibitipoca. In RC. Forzza, L. Menini Neto, F.R.G. Salimena \& D.C. Zappi (orgs.) Flora do Parque Estadual do Ibitipoca e seu entorno. Editora UFJF. Juiz de Fora, p. 15-26.

MEZABARBA, V., VIANNA FILHO, M.D.M., BORGES, R.A.X. \& MANSANO, V.F. 2013. Ericaceae do Parque Nacional do Itatiaia, RJ, Brasil. Hoehnea 40: 115-130.

OLIVEIRA-FILHO, A.T., FONTES, M.A.L., VIANA, P.L., VALENTE, A.S.M., SALIMENA, F.R.G. \& FERREIRA, F.M. 2013. O mosaico de fitofisionomias do Parque Estadual do Ibitipoca. In R.C. Forzza, L. Menini Neto, F.R.G. Salimena \& D.C. Zappi (orgs.) Flora do Parque Estadual do Ibitipoca e seu entorno. Editora UFJF. Juiz de Fora, p. 54-93.

RADFORD, A.E., DICKINSON, W.C., MASSEY, J.R. \& BELL, C.R. 1974. Vascular plant systematics. Harper Collins. New York.

RODELA, L.C. 1998. Cerrados de altitude e campos rupestres do Parque Estadual de Ibitipoca, sudeste de Minas Gerais: Distribuição e florística por subfisionomias da vegetação. Revta. Depto. Geogr. 12: 163-189.

ROMÃO, G.O. 2011. Revisão taxonômica de Gaylussacia Kunth (Ericaceae) e estudos da filogenia do gênero. Tese de Doutorado. Universidade Estadual de Campinas. Campinas.

ROMÃO, G.O. \& SOUZA, V.C. 2003. Flora fanerogâmica do Parque Nacional do Caparaó: Ericaceae. Pabstia 14: 1-12.
ROMÃO, G.O., WANDERLEY, M.G.L. \& YOKOYA, N. 2004. Flora de Grão-Mogol, Minas Gerais: Ericaceae. Bol. Bot. Univ. São Paulo 22: 97-100.

ROMÃO, G.O. \& SOUZA, V.C. 2014. Flora da Serra do Cipó, Minas Gerais: Ericaceae. Bol. Bot. Univ. São Paulo 32(1): 43-70.

SALIMENA-PIRES, F.R. 1997. Aspectos fisionômicos e vegetacionais do Parque Estadual do Ibitipoca, Minas Gerais, Brasil. In G.C. Rocha (coord.). Anais do 1ํ Seminário de Pesquisa sobre o Parque Estadual do Ibitipoca. Núcleo de Pesquisa em Zoneamento Ambiental da UFJF. Juiz de Fora, p. 61-60.

SILVA, R.R. \& CERVI, A.C. 2006. As Ericaceae Juss. nativas no Estado do Paraná, Brasil. Act. Biol. Paranaense 35: 1-45.

SLEUMER, H. 1959. Studien über die Gattung Leucothöe D. Don. Bot. Jahrb. Syst. 78(4): 435480.

SLEUMER, H. 1967. Die gattung Gaylussacia H.B.K. Botanische Jahrbücher für Systematik 86: 309-384.

SOUZA, V.C. \& LORENZI, H. 2012. Botânica Sistemática: guia ilustrado para identificação das famílias de Fanerógamas nativas e exóticas do Brasil, baseado em APG III. $3^{\text {a }}$ ed. Instituto Plantarum, Nova Odessa.

STEVENS, P.F. 1971. A classification of the Ericaceae: sub-families and tribes. Bot. J. Linn. Soc. $64: 1-53$.

TAKEUCHI, C. \& AFFONSO, P. 2009. Levantamento de Ericaceae Juss. no Núcleo Curucutu, Parque Estadual da Serra do Mar, São Paulo. Revta Inst. Flor. 21: 131-138.

VITTA, F. 2002. Diversidade e conservação da flora nos campos rupestres da Cadeia do Espinhaço em Minas Gerais. In E.L. Araújo, A.N. Moura, E.V.S.B. Sampaio, L.M.S. Gestinari \& J.M.T. Carneiro (eds.). Biodiversidade, conservação e uso sustentável da Flora do Brasil. Universidade Federal Rural de Pernambuco/Sociedade Botânica do Brasil. Recife, p. 90-94. 


\section{APÊNDICE I:}

\section{Lista de Materiais Examinados}

Amaral, M. C. E.: CFSC 8421 (3.6). Andrade, P.M.: 892 (3.5.2). Antunes, K.: 26 (1.1). Braga, P.I.S.: 1914 (3.4). Brugger, M.: s.n. CESJ 25309 (3.4), CESJ 25321 (3.2). Cabral, A: 50 (3.7), 72 (1.5), 74 (1.6), 75 (2.1), 76 (2.1), 77 (1.5), 78 (3.8), 81 (1.2), 82 (3.5.1), 83 (3.10), 84 (1.3), 85 (1.5), 87 (3.5.2), 88 (3.4), 89 (1.4), 91(1.3), 92 (3.4), 94 (1.3), 95 (3.4), 96 (3.10), 97 (3.4), 98 (3.3), 99 (3.4), 100 (3.10), 102 (1.6), 103 (3.7). Câmara, U.C.: s.n. CESJ 9350 (3.2), CESJ 9353 (2.1), CESJ 9464 (3.4). Castro, R.M: 213 (1.6), 221 (3.5.1). Confúcio, U: s.n. CESJ 9350 (3.1), CESJ 9401 (1.1). Eiterer, M.: 113 (3.5.2), s.n. CESJ 125814 (3.2), CESJ 24890 (1.2). Forzza, R.C.: 2441 (3.4), 2446 (3.3), 3121 (3.6), 3194 (2.1), 3498 (3.10), 3594 (3.3), 3931 (3.10), 4235 (1.2), 4264 (1.3), 4385 (3.6), s.n. CESJ 25696 (3.10). Giordano, L.C.: 2422 (2.1), 2423 (1.2), 2442 (1.5). Gomes, M.: 634 (3.5.1). Hellages: 2272 (3.1). Heluey, M.A.: 5 (1.2). Krieger, L.: s.n. CESJ 8657
(2.1), CESJ 9252 (3.4), CESJ 9264 (1.5), CESJ 9377 (3.1), CESJ 9395a (3.1), CESJ 9398 (1.2), CESJ 9462 (3.10), CESJ 13226 (1.5), CESJ 13229 (3.3), CESJ 13235 (3.4), CESJ 14623 (3.5.2). Luchi, A.E.: 429 (3.5.1). Magalhães, M.: 445 (3.8), 448 (3.10), 529 (3.4). Manhães, M.A.: 18 (3.5.2), 42 (3.10). Marquete, R.: 3100 (3.4). Medeiros, E.S.: 339 (3.4). Monteiro, R.F.: 5 (3.10). Nardy, C.: 31 (3.8), 34 (3.8). Oliveira, R.C.: 39 (3.4), 40 (3.10), 105 (3.3). Pereira, E.: 3200 (3.9). Ribeiro, J.H.C.: 193 (1.1). Rodela, L.G.: s.n. CESJ 31445 (3.3). Romão, G.O.: 3493 (1.3), 3494 (1.3), 3495 (1.3), 3496 (3.4), 3497 (3.10), 3498 (3.1), 3499 (3.3). Saavedra, M.M.: 194 (3.10), 207 (3.4). Saint-Hilaire, A.: 237 (3.5.1). Salimena, F.R.G.: 985 (3.3), 986 (3.4), s.n. CESJ 32702 (3.1), CESJ 26778 (3.4), CESJ 27547 (3.10). Schwacke, C.A.W.: 12342bis (3.9). Semir, J.: CFSC 5168 (3.6). Silva, B.R.: 1309 (1.2), 1350 (1.2), 1353 (1.3). Sobral, M.: 5604 (3.1). Souza, F.S.: 427 (1.1). Sucre, D.: 7216 (3.4). Tsuji, R.: 458 (3.2), 465 (3.2), 466a (3.2), 466b (3.4), 2458 (3.5.2). Valente, A.S.M.: 174 (2.1). Verardo, S.M.S.: s.n. CESJ 25368 (3.2), CESJ 25372 (3.10), CESJ 25381 (3.4). 